\title{
Structural Characterization of Wheat Straw Lignin as Revealed by Analytical Pyrolysis, 2D-NMR, and Reductive Cleavage Methods
}

\author{
José C. del Río, ${ }^{* \dagger}$ Jorge Rencoret, ${ }^{\dagger, \ddagger}$ Pepijn Prinsen, ${ }^{\dagger}$ Ángel T. Martínez, ${ }^{\S}$ John Ralph, ${ }^{\ddagger}$ \\ and Ana Gutiérrez ${ }^{\dagger}$ \\ ${ }^{\dagger}$ Instituto de Recursos Naturales y Agrobiología de Sevilla (IRNAS), CSIC, PO Box 1052, E-41080 Seville, Spain \\ ${ }^{\ddagger}$ Departments of Biochemistry and Biological Systems Engineering, the Wisconsin Bioenergy Initiative, and the DOE Great Lakes \\ Bioenergy Research Center, University of Wisconsin, Madison, Wisconsin 53706, United States \\ ${ }^{\S}$ Centro de Investigaciones Biológicas (CIB), CSIC, Ramiro de Maeztu 9, E-28040 Madrid, Spain
}

Supporting Information

ABSTRACT: The structure of the lignin in wheat straw has been investigated by a combination of analytical pyrolysis, $2 \mathrm{D}-$ $\mathrm{NMR}$, and derivatization followed by reductive cleavage (DFRC). It is a $p$-hydroxyphenyl-guaiacyl-syringyl lignin (with an $\mathrm{H}$ :G:S ratio of 6:64:30) associated with $p$-coumarates and ferulates. $2 \mathrm{D}$-NMR indicated that the main substructures present are $\beta$-O-4'ethers $(\sim 75 \%)$, followed by phenylcoumarans $(\sim 11 \%)$, with lower amounts of other typical units. A major new finding is that the flavone tricin is apparently incorporated into the lignins. NMR and DFRC indicated that the lignin is partially acylated $(\sim 10 \%)$ at the $\gamma$-carbon, predominantly with acetates that preferentially acylate guaiacyl (12\%) rather than syringyl (1\%) units; in dicots, acetylation is predominantly on syringyl units. $p$-Coumarate esters were barely detectable $(<1 \%)$ on monomer conjugates released by selectively cleaving $\beta$-ethers in DFRC, indicating that they might be preferentially involved in condensed or terminal structures.

KEYWORDS: wheat straw, Py-GC/MS, TMAH, HSQC, DFRC, milled wood lignin, p-coumarate, ferulate, coniferyl acetate, tricin

\section{INTRODUCTION}

Energy consumption has increased gradually over the last decades as the world population has grown and more countries have become industrialized. Crude oil has been the major resource used to meet the increased energy demand. However, concerns about declining of energy resources and the need to mitigate green-house gas emissions and decrease our dependency on fossil fuel reserves have focused attention on the use of plant biomass as a source for the production of biofuels and/or bioproducts. ${ }^{1}$

The first generation of biofuel feedstocks included sugar cane and cereal grains. Bioconversion of such crops to biofuels, however, competes with food production for land and has a considerable effect on food and feed prices. A promising alternative for second generation biofuels will come from cultivated lignocellulosic crops or agricultural wastes, which are available in high amounts at relatively low cost and could be a widely available and relatively inexpensive source for biofuels and/or bioproducts. Therefore, increasing attention is being paid to the use of lignocellulosic biomass as a renewable feedstock for the above industrial uses. ${ }^{2-4}$

Common lignocellulosic feedstocks considered for second generation biofuel production include woods (e.g., poplar or eucalyptus), perennial energy crops (e.g., switchgrass or Miscanthus species), and agricultural wastes (e.g., corn stover or cereal straws). Among them, wheat straw has the greatest potential of all agricultural residues because of its wide availability and low cost. ${ }^{4,5}$ Wheat straw is an abundant byproduct from wheat production in many countries. The average yield of wheat straw is $1.3-1.4 \mathrm{~kg} / \mathrm{kg}$ of wheat grain, with a world production of wheat estimated to be around 680 million tons in 2011. Wheat straw contains $35-45 \%$ cellulose, $20-30 \%$ hemicelluloses, and around $15 \%$ lignin, which makes it an attractive feedstock to be converted to ethanol and other value-added products.

The conversion of lignocellulosic biomass to bioethanol involves saccharification of carbohydrates to fermentable reducing sugars via hydrolysis and then fermentation of these free sugars to ethanol. However, the presence of lignin, a complex and amorphous polymer playing a major structural role in vascular plants, limits the accessibility of enzymes to cellulose, thus reducing the efficiency of the hydrolysis. ${ }^{1,6}$ Pretreatment of lignocellulosic materials to remove or modify the lignin is therefore needed to enhance the hydrolysis of carbohydrates. ${ }^{7,8}$ The efficiency of pretreatment methods is highly dependent on the lignin structure, and hence a knowledge of the structure of the lignin polymer in different plant species is important to develop appropriate pretreatment methods for lignin modification and/ or removal.

Lignin is a complex macromolecule synthesized by chemical polymerization of three main precursors, p-coumaryl (4hydroxycinnamyl), coniferyl (4-hydroxy-3-methoxycinnamyl), and sinapyl (3,5-dimethoxy-4-hydroxycinnamyl) alcohols, via enzymatically generated radicals. ${ }^{9}$ These monolignols produce the $p$-hydroxyphenyl $(\mathrm{H})$, guaiacyl (G), and syringyl (S) phenylpropanoid lignin units when incorporated into the lignin

Received: March 8, 2012

Revised: May 17, 2012

Accepted: May 21, 2012

Published: May 21, 2012 
polymer, units which are linked by several types of $\mathrm{C}-\mathrm{C}$ or ether bonds. The lignin composition depends on the botanical origin. Thus hardwood lignins are composed of $S$ and $G$ units in varying ratios, softwood lignin is composed of $\mathrm{G}$ units and small amounts of $\mathrm{H}$ units, and grass lignins include the three units (with $\mathrm{H}$-units still comparatively minor), making its structure apparently more complex. Additionally, $p$-hydroxycinnamates ( $p$-coumarates and ferulates) also widely occur in the structure of grass lignins, with $p$-coumarates mostly acylating the $\gamma-\mathrm{OH}$ of the lignin side chain, whereas ferulates and diferulates acylate cell wall polysaccharides and participate in both polysaccharide-polysaccharide and lignin-polysaccharide cross-coupling reactions, in the latter case becoming integrally bound into the lignin polymer. ${ }^{10}$

The composition and structure of the lignin in wheat straw has been a matter of study for many years. ${ }^{11-17}$ In this paper, a more in-depth and complete characterization of the lignin of wheat straw has been performed by the use of an array of analytical techniques, including Py-GC/MS (in the absence and in the presence of tetramethylammonium hydroxide, TMAH, as transesterification and methylating agent), 2D-NMR, and derivatization followed by reductive cleavage (DFRC), and important discrepancies with the data reported in previous papers have been found. In this work, lignin was also isolated from wheat straw according to the classical procedure of Björkman, ${ }^{18}$ to complement the analyses performed on whole lignocellulosic material. A knowledge of the composition and structure of wheat straw lignin will help to maximize the exploitation of this important agricultural waste as a feedstock for biofuels and other biorefinery products.

\section{MATERIALS AND METHODS}

Samples. Wheat straw (Triticum durum var. Carioca) was harvested from an experimental field in Seville (South Spain) in June 2009. Wheat straw was air-dried, and the dried samples were milled using a knife mill $(1 \mathrm{~mm}$ screen $)$ and successively extracted with acetone $(200 \mathrm{~mL})$ in a Soxhlet apparatus for $8 \mathrm{~h}$ (at which time the extracting solvent was clear and extractive-free) and hot water $\left(100 \mathrm{~mL}, 3 \mathrm{~h}\right.$ at $\left.100^{\circ} \mathrm{C}\right)$. Klason lignin content was estimated as the residue after sulfuric acid hydrolysis of the pre-extracted material, corrected for ash and protein content, according to the TAPPI method T222 om- $88 .{ }^{19}$ The acid-soluble lignin was determined, after the insoluble lignin was filtered off, by UVspectroscopic determination at $205 \mathrm{~nm}$ wavelength using $110 \mathrm{~L} \mathrm{~cm}^{-1}$ $\mathrm{g}^{-1}$ as the extinction coefficient. Holocellulose was isolated from the preextracted fibers by delignification for $4 \mathrm{~h}$ using the acid chlorite method. ${ }^{20}$ The $\alpha$-cellulose content was determined by removing the hemicelluloses from the holocellulose by alkali extraction. ${ }^{20}$ Ash content was estimated as the residue after $6 \mathrm{~h}$ of heating at $575^{\circ} \mathrm{C}$. Three replicates were used for each sample.

"Milled-Wood Lignin" (MWL) Isolation. The wheat straw MWL was obtained according to the classical method, ${ }^{18}$ from extractive-free wheat straw. The experimental procedure has been explained in detail in previous papers. ${ }^{21}$ The final yield was $\sim 20 \%$ based on the Klason lignin content of the original material.

Gel Permeation Chromatography (GPC). GPC of the isolated MWL was performed on a Shimadzu LC-20A liquid chromatography system (Shimadzu, Kyoto, Japan) equipped with a photodiode array detector (SPD-M20A; Shimadzu) using the following conditions: TSK gel $\alpha-\mathrm{M}+\alpha-2500$ (Tosoh, Tokyo, Japan) column; $0.1 \mathrm{M} \mathrm{LiBr}$ in dimethylformamide (DMF) eluent; $0.5 \mathrm{~mL} \mathrm{~min}{ }^{-1}$ flow rate; $40{ }^{\circ} \mathrm{C}$ column oven temperature; and $280 \mathrm{~nm}$ sample detection. The data acquisition and computation used LCsolution version 1.25 software (Shimadzu). The molecular weight calibration was via polystyrene standards.

Analytical Pyrolysis. Pyrolysis of wheat straw and the isolated MWL (approximately $100 \mu \mathrm{g}$ ) were performed with a 2020 microfurnace pyrolyzer (Frontier Laboratories Ltd.) connected to an Agilent
6890 GC/MS system equipped with a DB-1701 fused-silica capillary column ( $30 \mathrm{~m} \times 0.25 \mathrm{~mm}$ i.d., $0.25 \mu \mathrm{m}$ film thickness $)$ and an Agilent 5973 mass selective detector $(\mathrm{EI}$ at $70 \mathrm{eV})$. The pyrolysis was performed at $500{ }^{\circ} \mathrm{C}$. The GC oven temperature was programmed from $50{ }^{\circ} \mathrm{C}(1$ $\mathrm{min})$ to 100 at $30^{\circ} \mathrm{C} \mathrm{min}{ }^{-1}$ and then to $290{ }^{\circ} \mathrm{C}(10 \mathrm{~min})$ at $6{ }^{\circ} \mathrm{C} \mathrm{min}^{-1}$. Helium was the carrier gas $\left(1 \mathrm{~mL} \mathrm{~min}^{-1}\right)$. For Py/TMAH, $100 \mu \mathrm{g}$ of sample was mixed with approximately $0.5 \mu \mathrm{L}$ of TMAH $(25 \%, \mathrm{w} / \mathrm{w}$, in methanol), and the pyrolysis was carried out as described above. The compounds were identified by comparing their mass spectra with those of the Wiley and NIST libraries and those reported in the literature. ${ }^{22,23}$ Peak molar areas were calculated for the lignin-degradation products, the summed areas were normalized, and the data for two repetitive analyses were averaged and expressed as percentages.

NMR Spectroscopy. For NMR of the whole cell wall material, around $100 \mathrm{mg}$ of finely divided (ball-milled) extractive-free samples was swollen in $0.75 \mathrm{~mL}$ of DMSO- $d_{6}$ according to the method previously described. ${ }^{24,25}$ In the case of the MWL, around $40 \mathrm{mg}$ was dissolved in $0.75 \mathrm{~mL}$ of DMSO- $d_{6}$. NMR spectra were recorded at $25^{\circ} \mathrm{C}$ on a Bruker AVANCE III $500 \mathrm{MHz}$ instrument equipped with a cryogenically cooled $5 \mathrm{~mm}$ TCI gradient probe with inverse geometry (proton coils closest to the sample). HSQC (heteronuclear single quantum coherence) experiments used Bruker's "hsqcetgpsisp2.2" pulse program (adiabatic-pulsed version) with spectral widths of $5000 \mathrm{~Hz}$ (from 10 to 0 ppm) and $20,843 \mathrm{~Hz}$ (from 165 to $0 \mathrm{ppm}$ ) for the ${ }^{1} \mathrm{H}$ - and ${ }^{13} \mathrm{C}$ dimensions. The number of collected complex points was 2048 for the ${ }^{1} \mathrm{H}$-dimension with a recycle delay of $1.5 \mathrm{~s}$. The number of transients was 64 , and 256 time increments were always recorded in the ${ }^{13} \mathrm{C}$ dimension. The ${ }^{1} J_{\mathrm{CH}}$ used was $145 \mathrm{~Hz}$. Processing used typical matched Gaussian apodization in the ${ }^{1} \mathrm{H}$ dimension and squared cosine-bell apodization in the ${ }^{13} \mathrm{C}$ dimension. Prior to Fourier transformation, the data matrixes were zero-filled up to 1024 points in the ${ }^{13} \mathrm{C}$-dimension. The central solvent peak was used as an internal reference $\left(\delta_{\mathrm{C}} 39.5 ; \delta_{\mathrm{H}}\right.$ 2.49 ). Long range $J$-coupling evolution times of 66 and $80 \mathrm{~ms}$ were used in different heteronuclear multiple bond correlation (HMBC) acquisition experiments. HSQC correlation peaks were assigned by comparing with the literature. ${ }^{26-35}$ A semiquantitative analysis ${ }^{24,34,35}$ of the volume integrals (uncorrected) of the HSQC correlation peaks was performed using Bruker's Topspin 2.1 (Windows) or Topspin 3.1 (Mac) processing software. In the aliphatic oxygenated region, the relative abundances of side chains involved in the various interunit linkages were estimated from the $\mathrm{C}_{\alpha}-\mathrm{H}_{\alpha}$ correlations to avoid possible interference from homonuclear ${ }^{1} \mathrm{H}-{ }^{1} \mathrm{H}$ couplings, except for substructures $\mathbf{A}_{\mathbf{o x}}$ and $\mathbf{I}$, for which $\mathrm{C}_{\beta}-\mathrm{H}_{\beta}$ and $\mathrm{C}_{\gamma}-\mathrm{H}_{\gamma}$ correlations had to be used. In the aromatic/unsaturated region, $\mathrm{C}_{2}-\mathrm{H}_{2}$ correlations from $\mathrm{H}$, $\mathrm{G}$, and $\mathrm{S}$ lignin units and from $p$-coumarate and ferulate were used to estimate their relative abundances. Note that $p$-coumarate and ferulate quantitation relative to the lignin is overestimated due to the longer relaxation times of these end-units compared to the rapidly relaxing polymer and the more extensive relaxation the latter experiences during the significant duration of the pulse experiment itself.

DFRC (Derivatization Followed by Reductive Cleavage). DFRC degradation was performed according to the developed protocol. ${ }^{36-38}$ Lignins $(10 \mathrm{mg})$ were stirred for $2 \mathrm{~h}$ at $50{ }^{\circ} \mathrm{C}$ with acetyl bromide in acetic acid $(8: 92, \mathrm{v} / \mathrm{v})$. The solvents and excess acetyl bromide were removed by rotary evaporation at reduced pressure. The products were then dissolved in dioxane/acetic acid/water (5:4:1, v/v/ $\mathrm{v})$, and $50 \mathrm{mg}$ of powdered $\mathrm{Zn}$ was added. After $40 \mathrm{~min}$ stirring at room temperature, the mixture was transferred into a separatory funnel with dichloromethane and saturated ammonium chloride. The $\mathrm{pH}$ of the aqueous phase was adjusted to less than 3 by adding $3 \%$ aqueous $\mathrm{HCl}$, the mixture vigorously mixed, and the organic layer separated. The water phase was extracted twice more with dichloromethane. The combined dichloromethane fractions were dried over anhydrous $\mathrm{Na}_{2} \mathrm{SO}_{4}$, and the filtrate was evaporated on a rotary evaporator. The residue was acetylated for $1 \mathrm{~h}$ in $1.1 \mathrm{~mL}$ of dichloromethane containing $0.2 \mathrm{~mL}$ of acetic anhydride and $0.2 \mathrm{~mL}$ of pyridine. The acetylated lignin degradation products were collected after rotary evaporation of the solvents, and subsequently analyzed by GC/MS. To assess the presence of naturally acetylated lignin units, the described modification of the 
standard DFRC method using propionylating instead of acetylating reagents (DFRC'), as previously published, ${ }^{31,39,40}$ was used.

GC/MS analyses were performed with a GCMS-QP2010plus instrument (Shimadzu Co.) using a capillary column (SHR5XLB 30 $\mathrm{m} \times 0.25 \mathrm{~mm}$ i.d., $0.25 \mu \mathrm{m}$ film thickness). The oven was heated from $140{ }^{\circ} \mathrm{C}(1 \mathrm{~min})$ to 250 at $3{ }^{\circ} \mathrm{C} \mathrm{min}^{-1}$, then ramped at $10^{\circ} \mathrm{C} \mathrm{min}^{-1}$ to 280 ${ }^{\circ} \mathrm{C}(1 \mathrm{~min})$ and finally ramped at $20^{\circ} \mathrm{C} \mathrm{min}^{-1}$ to $300^{\circ} \mathrm{C}$, and held for 18 min at the final temperature. The injector was set at $250{ }^{\circ} \mathrm{C}$, and the transfer line was kept at $310^{\circ} \mathrm{C}$. Helium was used as the carrier gas at a rate of $1 \mathrm{~mL} \mathrm{~min}^{-1}$. Quantitation of the released individual monomers was performed using 4,4'-ethylenebisphenol as internal standard. Molar yields were calculated on the basis of molecular weights of the respective acetylated and/or propionylated compounds.

\section{RESULTS AND DISCUSSION}

The relative abundances of the main constituents of wheat straw (water-soluble material, acetone extractives, Klason lignin, acid soluble lignin, hemicelluloses, cellulose, and ash) are presented in Table 1. The lignin content (16.2\% Klason lignin), as well as the

Table 1. Abundance of the Main Constituents of Wheat Straw (\% Dry Weight)

$\begin{array}{lr}\text { water-solubles } & 9.6 \\ \text { acetone extractives } & 2.7 \\ \quad \text { lipophilics (\% of acetone extractives) } & 73.4 \\ \quad \text { polars (\% of acetone extractives) } & 26.6 \\ \text { Klason lignin }^{a} & 16.2 \\ \text { acid-soluble lignin }^{\text {holocellulose }} \quad r .5 \\ \quad \text { cellulose } & 58.9 \\ \quad \text { hemicelluloses } & 32.0 \\ \text { ash } \quad 26.9 \\ { }^{a} \text { Corrected for proteins and ash. }\end{array}$

content of the other main constituents (i.e., cellulose, hemicelluloses, etc.), agrees well with the data reported in previous papers. ${ }^{13,14,41,42}$ In this work, we have analyzed in detail the structural characteristics of the lignin polymer in wheat straw. For this, we analyzed first the composition of the lignin in situ by PyGC/MS (both in the absence and in the presence of TMAH), and 2D-NMR. Then, for a more detailed structural characterization, the lignin (often termed a "milled wood lignin" or MWL) was isolated by aqueous dioxane extraction from finely ballmilled wheat straw according to the classical lignin isolation procedure. $^{18}$

Molecular Weight Distribution of Wheat Straw MWL. The values of the weight-average $\left(M_{\mathrm{w}}\right)$ and number-average $\left(M_{n}\right)$ molecular weights were estimated from the GPC curves (relative values related to polystyrene standards). The MWL exhibited a weight-average $\left(M_{\mathrm{w}}\right)$ molecular weight of $4210 \mathrm{~g}$ $\mathrm{mol}^{-1}$ and a number-average $\left(M_{\mathrm{n}}\right)$ molecular weight of 1850 . In addition, the MWL exhibited relatively narrow polydispersity, with $M_{\mathrm{w}} / M_{n}$ of 2.27 . The $M_{\mathrm{w}}$ value is comparable to, or even slightly higher than, values previously reported for the lignin in wheat straw. ${ }^{14,42}$

Py-GC/MS of Wheat Straw and Its Isolated MWL. The chemical composition of the lignin in wheat straw was analyzed in situ, without prior isolation, by Py-GC/MS. In addition, the isolated MWL was also analyzed by Py-GC/MS. The pyrograms of wheat straw and its isolated MWL are shown in Figure 1. The identities and relative abundances of the lignin-derived compounds released are listed in Table 2.
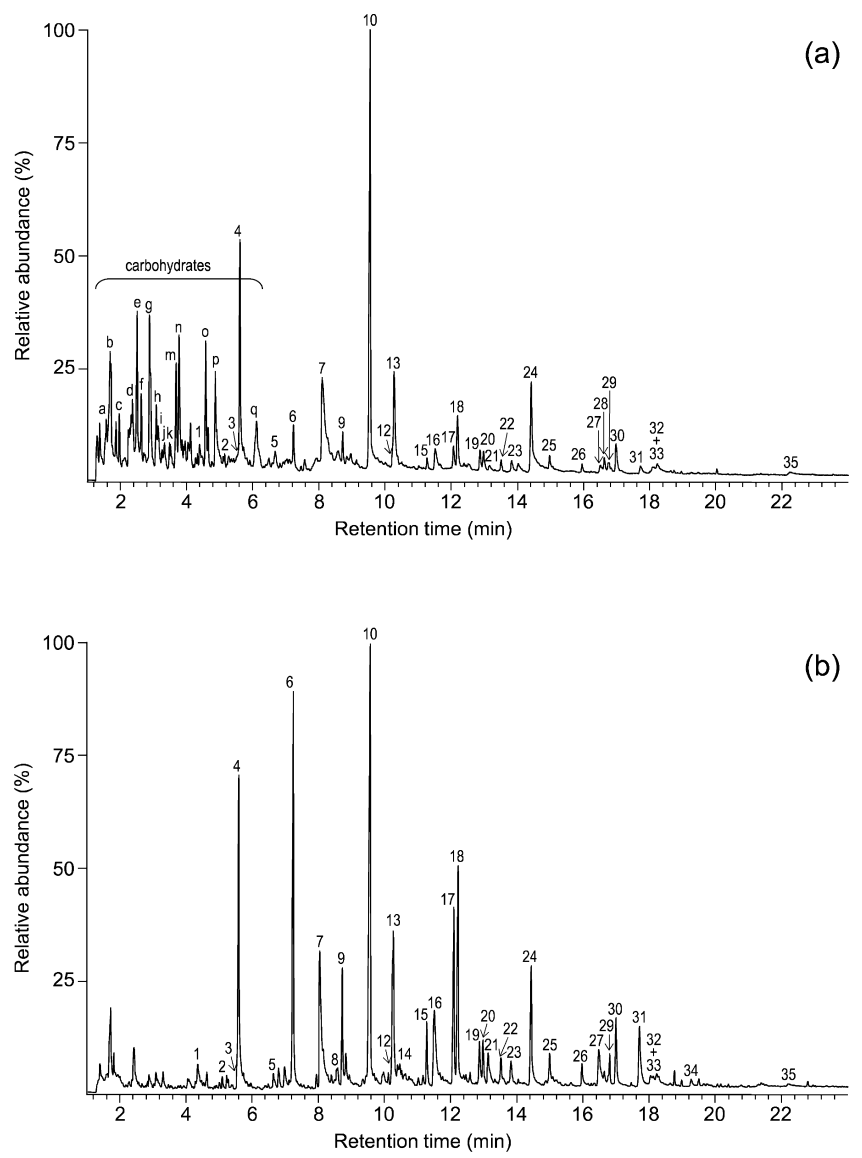

Figure 1. Py-GC/MS chromatograms of wheat straw (a) and of the isolated MWL (b). The identities and relative abundances of the ligninderived phenolic compounds released are listed in Table 2. Letters refer to carbohydrate compounds: (a) 2-methylfuran; (b) hydroxyacetaldehyde; (c) 3-hydroxypropanal; (d) (3H)-furan-2-one; (e) propanal; (f) $(2 \mathrm{H})$-furan-3-one; (g) furfural; (h) 1-acetoxypyran-3-one; (i) 2hydroxymethylfuran; (j) cyclopent-1-ene-3,4-dione; $(\mathrm{k})(5 \mathrm{H})$-furan-2one; (m) 2,3-dihydro-5-methylfuran-2-one; (n) 2-acetylfuran; (o) 4hydroxy-5,6-dihydro-(2H)-pyran-2-one; (p) 2-hydroxy-3-methyl-2-cyclopenten-1-one; (q) 3-hydroxy-2-methyl-(4H)-pyran-4-one.

Pyrolysis of wheat straw (Figure 1a) released compounds derived from the carbohydrate, lignin, and $p$-hydroxycinnamate moieties. $p$-Hydroxycinnamates, in addition to being the precursors of monolignols, are widely present as such in herbaceous plants ${ }^{10,13,43-46}$ and efficiently produce upon pyrolysis similar compounds as those derived from lignin, such as 4-vinylphenol (from $p$-coumarates) and 4-vinylguaiacol (from ferulates), which will overestimate the composition of the $\mathrm{H}$ - and G-lignin units and affect the calculation of the $S / G$ ratio unless they are left out of the calculation. ${ }^{21}$ The important amounts of 4vinylphenol $(\sim 17 \%$ of all phenolic compounds) and 4vinylguaiacol ( $\sim 28 \%$ of all phenolic compounds) released upon pyrolysis from wheat straw indicate the presence of $p$ coumarates and ferulates in this sample, as will be shown below. It is obvious then that these vinyl compounds cannot be used for the estimation of the lignin H:G:S composition upon Py-GC/ MS, as the major part of them do not arise from the core lignin structural units but from $p$-hydroxycinnamates. An estimation of the $S / G$ ratio of the lignin in wheat straw was, however, performed by ignoring 4-vinylguaiacol (and the analogous 4vinylsyringol) and revealed a value of 0.5 (Table 2 ). 
Table 2. Identities and Relative Abundances of the Lignin-Derived Phenolic Compounds Released after Py-GC/MS of Wheat Straw and the Isolated MWL

\begin{tabular}{|c|c|c|c|c|c|}
\hline \multirow[b]{2}{*}{ label } & \multirow[b]{2}{*}{ compound } & \multirow[b]{2}{*}{ MW } & \multirow[b]{2}{*}{ origin $^{a}$} & \multicolumn{2}{|c|}{ wheat straw } \\
\hline & & & & cell walls & MWL \\
\hline 1 & phenol & 94 & $\mathrm{H}$ & 2.3 & 2.4 \\
\hline 2 & 2-methylphenol & 108 & $\mathrm{H}$ & 0.8 & 0.5 \\
\hline 3 & 4-methylphenol & 108 & $\mathrm{H}$ & 1.3 & 2.8 \\
\hline 4 & guaiacol & 124 & G & 11.0 & 8.4 \\
\hline 5 & C2-phenol & 122 & $\mathrm{H}$ & 0.3 & 0.3 \\
\hline 6 & 4-methylguaiacol & 138 & G & 3.7 & 12.0 \\
\hline 7 & 4-vinylphenol & 120 & $\mathrm{H} / \mathrm{PCA}$ & 16.9 & 10.8 \\
\hline 8 & 4-allylphenol & 134 & $\mathrm{H}$ & 0.0 & 0.4 \\
\hline 9 & 4-ethylguaiacol & 152 & G & 1.4 & 2.9 \\
\hline 10 & 4-vinylguaiacol & 150 & G/FA & 27.7 & 14.8 \\
\hline 11 & cis-4-propenylphenol & 134 & $\mathrm{H}$ & 0.0 & 0.1 \\
\hline 12 & eugenol & 164 & G & 0.9 & 1.4 \\
\hline 13 & syringol & 154 & $S$ & 6.9 & 6.9 \\
\hline 14 & trans-4-propenylphenol & 134 & $\mathrm{H}$ & 0.0 & 0.4 \\
\hline 15 & cis-isoeugenol & 164 & G & 0.5 & 1.5 \\
\hline 16 & vanillin & 152 & G & 2.7 & 5.3 \\
\hline 17 & 4-methylsyringol & 168 & $S$ & 1.3 & 4.8 \\
\hline 18 & trans-isoeugenol & 164 & G & 2.7 & 5.1 \\
\hline 19 & 4-propinylguaiacol & 162 & G & 1.2 & 1.2 \\
\hline 20 & 4-allenylguaiacol & 162 & G & 1.3 & 1.3 \\
\hline 21 & acetoguaiacone & 166 & G & 0.4 & 1.7 \\
\hline 22 & 4-ethylsyringol & 182 & $S$ & 0.6 & 0.8 \\
\hline 23 & guaiacylacetone & 180 & G & 0.8 & 0.7 \\
\hline 24 & 4-vinylsyringol & 180 & $S$ & 6.7 & 3.6 \\
\hline 25 & 4-allylsyringol & 194 & S & 0.6 & 1.0 \\
\hline 26 & cis-4-propenylsyringol & 194 & $S$ & 0.5 & 0.7 \\
\hline 27 & syringaldehyde & 182 & $\mathrm{~S}$ & 0.9 & 2.2 \\
\hline 28 & 4-propinylsyringol & 192 & $S$ & 0.6 & 0.2 \\
\hline 29 & 4-allenylyringol & 192 & $S$ & 0.6 & 0.2 \\
\hline 30 & trans-propenylsyringol & 194 & $S$ & 1.7 & 1.8 \\
\hline 31 & acetosyringone & 196 & S & 0.6 & 2.3 \\
\hline 32 & trans-coniferaldehyde & 178 & G & 1.8 & 1.0 \\
\hline 33 & syringylacetone & 210 & $S$ & 0.4 & 0.2 \\
\hline 34 & propiosyringone & 210 & S & 0.0 & 0.2 \\
\hline \multirow[t]{2}{*}{35} & trans-sinapaldehyde & 208 & $\mathrm{~S}$ & 0.7 & 0.3 \\
\hline & & & & 0.5 & 0.5 \\
\hline
\end{tabular}

${ }^{a} \mathrm{H}$ : lignin $p$-hydroxyphenyl-type. G: lignin guaiacyl-type. S: lignin syringyl-type. PCA: $p$-coumarate. FA: ferulate. ${ }^{b}$ All G- and S-derived peaks were used for the estimation of the $\mathrm{S} / \mathrm{G}$ ratio, except 4-vinylguaiacol (which also arises from ferulates), and the analogous 4-vinylsyringol.

Pyrolysis of the MWL isolated from wheat straw (Figure $1 \mathrm{~b}$ ) released a similar distribution of cinnamate and lignin-derived compounds, except for the relatively lower abundance of 4vinylguaiacol (10), which is still the most predominant compound in the pyrogram of MWL, and the much higher abundance of 4-methylguaiacol (6). The S/G ratio of the MWL (estimated as above, by ignoring the 4-vinylguaiacol and its analogous 4-vinylsyringol) is similar to that observed in the whole cell walls (S/G 0.5). These results confirm that the lignin in wheat straw is an $\mathrm{H}: \mathrm{G}: \mathrm{S}$ lignin, in agreement with other papers, ${ }^{11,13,14,16,39}$ but in sharp contrast with the results from Banoub et al., ${ }^{15}$ which indicated the complete absence of S-lignin units in the lignin of wheat straw.

The occurrence of $p$-hydroxycinnamates in the cell walls of wheat straw, as well as in the isolated MWL, was assessed by pyrolysis in the presence of TMAH,,$^{21,46,47}$ as shown in Figure 2. The identities of the compounds released and their relative abundances are listed in Table 3. Py/TMAH induces cleavage of the $\beta$-O-4-ether bonds in the lignin and released products similar to those obtained upon $\mathrm{CuO}$ alkaline degradation, ${ }^{41}$ including methylated aldehydes (peaks 6, 12, and 19), ketones (peaks 15 and 24), and acids (peaks 10, 17, and 26). ${ }^{21,46,47} \mathrm{Py} / \mathrm{TMAH}$ also induces transesterification of the $p$-hydroxycinnamate esters, and breakdown of ether linkages at $\mathrm{C}_{4}$, with subsequent methylation of the phenolic hydroxyl groups. ${ }^{21,46,47}$ As seen in Figure 2, Py/ TMAH of wheat straw released important amounts (over $15 \%$ of total peak areas) of the dimethyl derivative of $p$-coumaric acid (peak 25), as well as similar amounts (13\% of total peak area) of the methyl derivative of ferulic acid (peak 30). In addition to the trans-forms, minor amounts of the cis-isomers (peaks 18 and 28) were also identified. An estimation of the $S / G$ ratio can now be performed with fewer restrictions than in the case of conventional pyrolysis because the compounds derived from lignin and $p$-hydroxycinnamates are now clearly differentiated (Table 3). The value was similar in the cell walls and the MWL (S/G 0.5) samples, and was also similar to that estimated by Py-GC/MS (by ignoring 4-vinylguaiacol and 4-vinylsyringol). The relative abundances of $p$-hydroxycinnamates ( $p$-coumarate/ferulate 

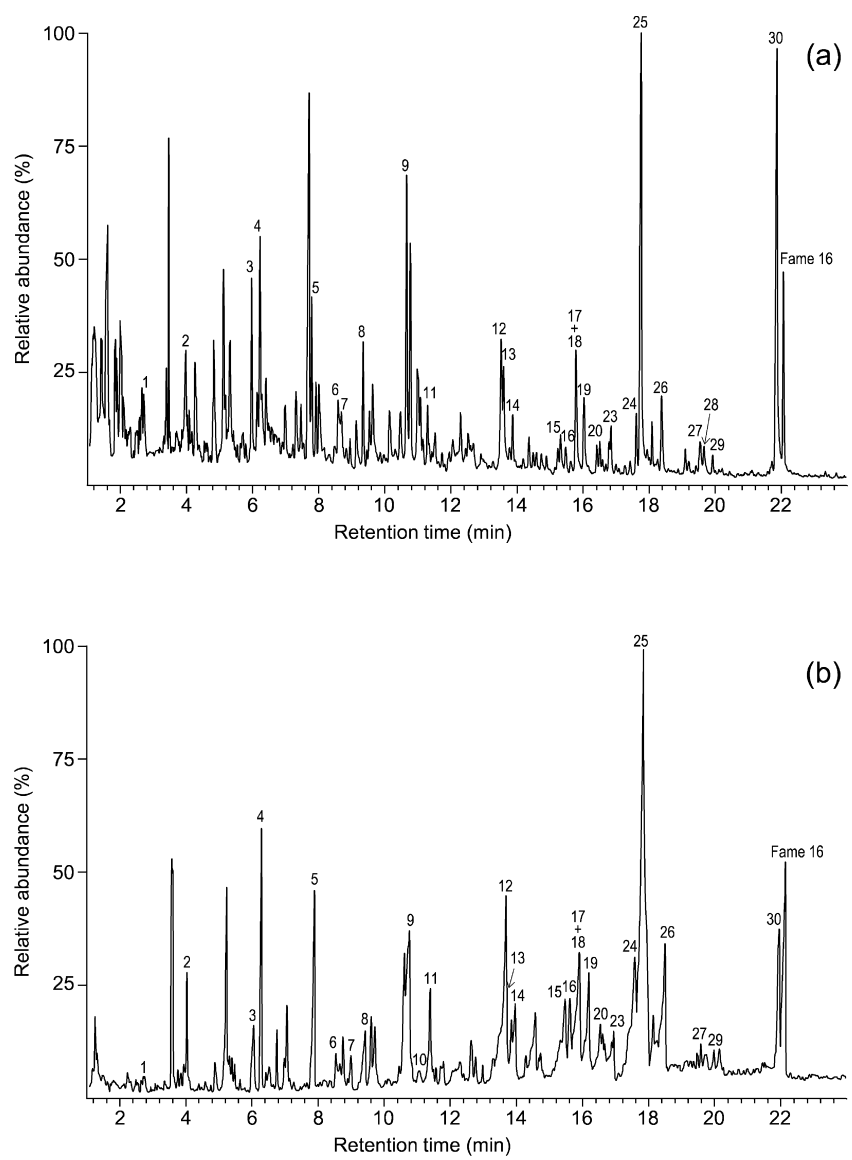

Figure 2. Py-TMAH-GC/MS chromatograms of wheat straw (a) and of the isolated MWL (b). The identities and relative abundances of the released compounds are listed in Table 3. Fame 16: hexadecanoate methyl ester.

ratio) present in wheat straw and the isolated MWL, estimated by Py/TMAH (Table 3), revealed additional features. Both $p$ coumarate and ferulate are present in the whole cell walls of wheat straw in similar abundances, whereas in the isolated MWL $p$-coumarate was released in higher relative abundance $(\sim 22 \%$ of the Py/TMAH products analyzed) than ferulate $(\sim 4 \%)$. These data, therefore, indicate that ferulate is mostly attached to carbohydrates while $p$-coumarate is predominantly attached to the lignin polymer. Previous studies have indicated that the bulk of $p$-coumarate in wheat straw is esterified to the lignin side chains ${ }^{13}$ and, more specifically, acylates the $\gamma-\mathrm{OH}$ of the lignin side chain, ${ }^{11}$ as established for other grasses. ${ }^{26}$ Ferulates, on the other hand, have previously been supposed to be mostly etherified at the $\alpha$ - and $\beta$-carbons contributing to lignincarbohydrate bridges. ${ }^{48}$ Recent studies have concluded that ferulates are an intrinsic part of the lignin structure in grasses, participating in coupling and cross-coupling reactions with other monolignols. ${ }^{10}$

2D-NMR of Wheat Straw and Its Isolated MWL. In order to obtain additional information on the structure of the lignin, the whole cell walls of wheat straw were analyzed in situ by gel state $2 \mathrm{D}-\mathrm{NMR}$, according to the method previously described, ${ }^{24,25}$ and the spectrum was compared with that of the isolated MWL. The acetylated MWL was also analyzed by HSQC (not shown) to confirm the assignments of the correlation peaks.

The side-chain $\left(\delta_{\mathrm{C}} / \delta_{\mathrm{H}} 50-90 / 2.5-5.8\right)$ and the aromatic/ unsaturated $\left(\delta_{\mathrm{C}} / \delta_{\mathrm{H}} 90-155 / 6.0-8.0\right)$ regions of the HSQC
NMR spectra of the whole cell walls from wheat straw, and its isolated MWL, are shown in Figure 3. Polysaccharide signals, dominated by hemicellulose correlations as cellulose signals are hardly detectable in the gel state, ${ }^{24}$ were predominant in the spectrum of the whole cell walls, including xylan correlations in the range $\delta_{\mathrm{C}} / \delta_{\mathrm{H}} 60-85 / 2.5-5.5$ (for $\mathrm{X}_{2}, \mathrm{X}_{3}, \mathrm{X}_{4}$, and $\mathrm{X}_{5}$ ), which partially overlapped with some lignin signals, and signals from natively acetylated xylan moieties $\left(\mathrm{X}_{2}^{\prime}\right.$ and $\left.\mathrm{X}_{3}^{\prime}\right)$. Lignin signals could also be clearly observed in the HSQC spectrum of the whole cell walls, despite its moderate lignin content (16.2\% Klason lignin). On the other hand, the spectrum of the MWL presented mostly lignin signals that, in general terms, matched those observed in the HSQC spectrum of the whole cell walls, but improved the detection of more minor lignin structures. The main lignin correlation peaks assigned in the HSQC spectra are listed in Table 4, and the main substructures found are depicted in Figure 4.

Interunit Linkage Characterization. The aliphatic-oxygenated region of the spectra (Figure 3, top) gave information about the different interunit linkages present in the lignin. In this region, correlation peaks from methoxyls and side chains in $\beta$-O4 ' substructures (A) were the most prominent in the HSQC spectra of the whole cell walls and the isolated MWL. Other substructures were more clearly visible in the HSQC spectrum of the MWL, including signals for phenylcoumarans (B), resinols (C), dibenzodioxocins (D), and spirodienones (F). Minor amounts of $\alpha, \beta$-diaryl ether substructures (E) could also be detected in the HSQC of the MWL, as revealed by the $\mathrm{C}_{\alpha}-\mathrm{H}_{\alpha}$ correlation at $\delta_{\mathrm{C}} / \delta_{\mathrm{H}} 79.5 / 5.50$, although they were not detected in previous works. ${ }^{11}$ It is important to note that $\alpha, \beta$-diaryl ether linkages are usually either undetectable or present at very low levels, although significant amounts have been found to occur in tobacco lignin. ${ }^{49} p$-Hydroxycinnamates, particularly ferulates, have been claimed to be etherified at the benzyl $(\alpha)$ position of the lignin side chain. ${ }^{12}$ However, the $\alpha$-hydroxycinnamate ethers are shifted from this position, indicating that only normal lignin $\alpha$-ethers can be detected and that $\alpha$-etherification by hydroxycinnamates is insignificant.

Lignin Acylation. The HSQC spectrum of the isolated wheat straw MWL also readily reveals the presence of characteristic signals corresponding to the $\mathrm{C}_{\gamma}-\mathrm{H}_{\gamma}$ correlations of $\gamma$-acylated $\beta$ $O-4^{\prime}\left(\mathbf{A}^{\prime}\right)$ and other structures in the range from $\delta_{\mathrm{C}} / \delta_{\mathrm{H}} 63.5 / 3.83$ and $\sim 4.30$. Signals for $\alpha$-acylated $\beta-O-4^{\prime}$ substructures, which should appear at $\sim 6.1 / 75 \mathrm{ppm}$, were not observed in the spectrum. Therefore, it is possible to conclude that the lignin of wheat straw is partially acylated and that this acylation occurs exclusively at the $\gamma$-position of the lignin side chain, as already observed in this and other grasses. ${ }^{11,21,26}$ In addition, a signal for the $\mathrm{C}_{\beta}-\mathrm{H}_{\beta}$ correlations of $\gamma$-acylated $\beta$-O-4' substructures linked to a G-unit $\left(\mathrm{A}_{\beta(\mathrm{G})}^{\prime}\right)$ is clearly observed at $\delta_{\mathrm{C}} / \delta_{\mathrm{H}} 80.8 / 4.52{ }^{21}$ indicating an important acylation extent of G-lignin units in this lignin, as will be discussed below. An estimate of $\sim 10 \%$ for the percentage of $\gamma$-acylation of lignin side chains was calculated by integration of the $\mathrm{C}_{\gamma}-\mathrm{H}_{\gamma}$ correlation peaks corresponding to the hydroxylated $\left(\mathrm{A}_{\gamma}\right)$ and acylated $\left(\mathrm{A}_{\gamma}^{\prime}\right)$ substructures in the HSQC spectrum of the isolated MWL (Table 5).

Lignin Aromatic/Unsaturated Components. The main correlation peaks in the aromatic/unsaturated region of the HSQC spectra (Figure 3, bottom) corresponded to the aromatic rings and unsaturated side chains of the different lignin units and hydroxycinnamates (plus one "new" feature, to be described below). Signals from $p$-hydroxyphenyl $(\mathbf{H})$, guaiacyl $(\mathbf{G})$, and syringyl (S) units were observed almost equivalently in the 
Table 3. Identity and Relative Abundances of the Compounds Released after Py/TMAH of Wheat Straw and the Isolated MWL

\begin{tabular}{|c|c|c|c|c|c|}
\hline \multirow[b]{2}{*}{ label } & \multirow[b]{2}{*}{ compound } & & \multirow[b]{2}{*}{$M_{\mathrm{w}}$} & \multicolumn{2}{|c|}{ wheat straw } \\
\hline & & & & cell walls & MWL \\
\hline 1 & methoxybenzene & & 108 & 2.4 & 0.7 \\
\hline 2 & 4-methoxytoluene & & 122 & 4.4 & 2.6 \\
\hline 3 & 1,2-dimethoxybenzene & & 138 & 5.9 & 2.8 \\
\hline 4 & 4-methoxystyrene & & 134 & 8.0 & 6.3 \\
\hline 5 & 3,4-dimethoxytoluene & & 152 & 4.7 & 5.6 \\
\hline 6 & 4-methoxybenzaldehyde & & 136 & 2.5 & 1.1 \\
\hline 7 & trans-4-methoxypropenylbenzene & & 148 & 1.0 & 1.0 \\
\hline 8 & 1,2,3-trimethoxybenzene & & 168 & 3.6 & 2.4 \\
\hline 9 & 3,4-dimethoxystyrene & & 164 & 8.6 & 7.5 \\
\hline 10 & 4-methoxybenzoic acid methyl ester & & 166 & 0.7 & 0.7 \\
\hline 11 & 3,4,5-trimethoxytoluene & & 182 & 1.8 & 2.6 \\
\hline 12 & 3,4-dimethoxybenzaldehyde & & 166 & 5.2 & 11.2 \\
\hline 13 & 1-(3,4-dimethoxyphenyl)-1-propene & & 178 & 3.5 & 1.9 \\
\hline 14 & 3,4,5-trimethoxystyrene & & 194 & 1.2 & 2.0 \\
\hline 15 & 3,4-dimethoxyacetophenone & & 180 & 1.4 & 2.9 \\
\hline 16 & 1-(3,4-dimethoxyphenyl)-2-propanone & & 194 & 1.0 & 2.4 \\
\hline 17 & 3,4-dimethoxybenzoic acid methyl ester & & 196 & 3.5 & 4.5 \\
\hline 18 & cis-3-(4-methoxyphenyl)-3-propenoic acid methyl ester & & 192 & 0.6 & 0.8 \\
\hline 19 & 3,4,5-trimethoxybenzaldehyde & & 196 & 2.4 & 3.6 \\
\hline 20 & 3,4-dimethoxybenzeneacetic acid methyl ester & & 210 & 0.7 & 1.6 \\
\hline 21 & cis-1-(3,4dimethoxyphenyl)-2-methoxyethylene & & 194 & 0.8 & 1.1 \\
\hline 22 & trans-1-(3,4dimethoxyphenyl)-2-methoxyethylene & & 194 & 0.7 & 0.7 \\
\hline 23 & 1-(3.4.5-trimethoxyphenyl)-1-propene & & 208 & 1.0 & 0.8 \\
\hline 24 & 3,4,5-trimethoxyacetophenone & & 210 & 1.6 & 5.4 \\
\hline 25 & trans-3-(4-methoxyphenyl)-3-propenoic acid methyl ester & & 192 & 15.1 & 18.8 \\
\hline 26 & 3,4,5-trimethoxybenzoic acid methyl ester & & 226 & 2.3 & 3.6 \\
\hline 27 & cis-1-(3,4,5-trimethoxyphenyl)-2-methoxyethylene & & 224 & 1.1 & 0.5 \\
\hline 28 & cis-3-(3,4-dimethoxyphenyl)-3-propenoic acid methyl ester & & 222 & 0.9 & 0.2 \\
\hline 29 & trans-1-(3,4,5-trimethoxyphenyl)-2-methoxyethylene & & 224 & 0.5 & 0.5 \\
\hline \multirow[t]{3}{*}{30} & trans-3-(3,4-dimethoxyphenyl)-3-propenoic acid methyl ester & & 222 & 13.2 & 4.3 \\
\hline & & $\mathrm{S} / \mathrm{G}$ ratio & & 0.4 & 0.5 \\
\hline & & $p$-coumarate/ferulate ratio ${ }^{a}$ & & 1.1 & 4.3 \\
\hline
\end{tabular}

${ }^{a}$ Relative abundance of $p$-coumarates (peaks 18 and 25) with respect to ferulates (peaks 28 and 30).

spectra of the whole cell walls and in the isolated MWL, due to this region's being purely derived from such structures (and completely free of the polysaccharide correlations that can overwhelm other regions of the spectrum). In addition, as is typical in spectra from grasses, prominent signals corresponding to $p$-coumarate (PCA) and ferulate (FA) structures were also observed. HSQC analysis of the acetylated MWL (not shown) indicated that the $p$-coumarate phenol is free, not etherified. Therefore, $p$-coumarates in wheat straw lignin are solely ester linked, as already advanced by other authors, ${ }^{13}$ and as found in other grasses. ${ }^{21,26}$ Other signals in this region of the spectrum are from the unsaturated side chains of cinnamyl alcohol end-groups (I) and cinnamaldehyde end-groups ( $\mathrm{J}$ ). The total relative content of the cinnamaldehyde end-groups was estimated by comparison of the intensities of the $\mathrm{C}_{\beta}-\mathrm{H}_{\beta}$ correlations in cinnamyl alcohols (I) and aldehydes (J).

Identification of a New Component in Wheat Lignin. We also report here on the successful structural elucidation of an initially puzzling component giving unusual correlation peaks in the aromatic regions of HSQC spectra, and provide the first evidence that a flavone is linked to lignin in wheat and, apparently, other grasses. Two strong and well-resolved signals from unknown structures, not previously reported in lignin, were readily observed at $\delta_{\mathrm{C}} / \delta_{\mathrm{H}} 94.1 / 6.56$ and $98.8 / 6.20$ in the HSQC spectra, Figure 3 (bottom). Their appearance in the spectrum of the whole cell walls indicated that they did not arise from impurities or artifacts formed during the lignin isolation process, and their retention in the MWL suggested that they might belong to structures bound into the lignin network. Interestingly, these signals can also be observed in the published HSQC spectra of another lignin preparation from wheat straw, ${ }^{14}$ although they were not assigned in that paper. Likewise, we have also noticed the occurrence of these two signals in the lignins from other grasses, such as elephant grass, and they have remained a mystery. Their prevalence in these wheat spectra made it imperative that we attempt to identify the component. Further valuable information about the nature of this structure was obtained by performing long-range ${ }^{13} \mathrm{C}-{ }^{1} \mathrm{H}$ correlation (HMBC) experiments (Figure 5). The correlation peaks between protons and carbons separated by $2-3$ bonds observed in the HMBC spectrum clearly indicate that this moiety has a flavone-type structure. Flavones are a class of flavonoids that have the 2-phenylchromen-4-one backbone. There is a high diversity of flavones that arise from the different phenolic hydroxyl group substitutions and include compounds such as luteolin or apigenin. From the proton and carbon (including quaternary 

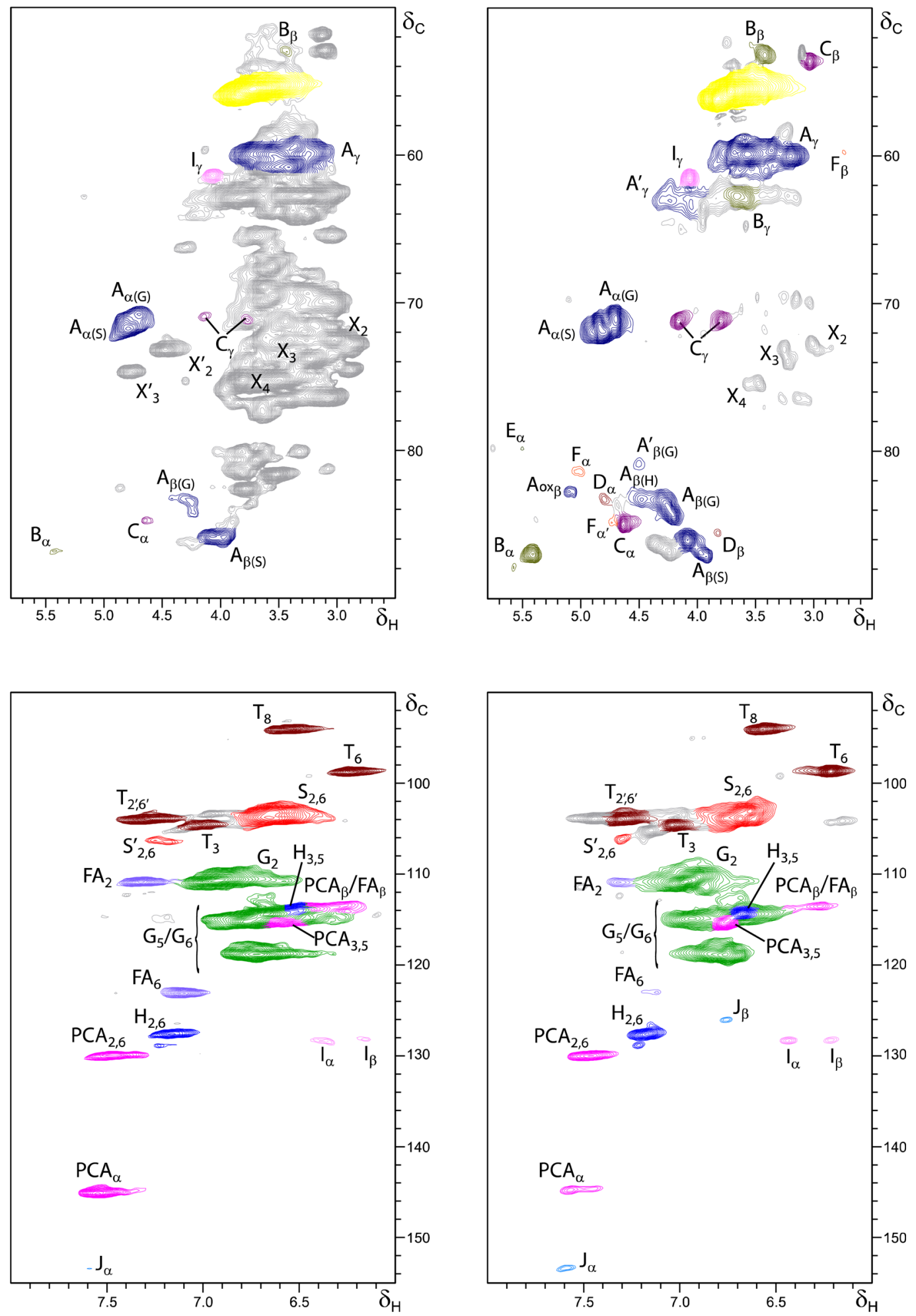

Figure 3. Side chain $\left(\delta_{\mathrm{C}} / \delta_{\mathrm{H}} 50-90 / 2.5-5.8\right)$ and aromatic/unsaturated $\left(\delta_{\mathrm{C}} / \delta_{\mathrm{H}} 90-155 / 5.5-8.0\right)$ regions in the 2D HSQC NMR spectra of wheat straw cell walls (left) and of the isolated MWL (right). See Table 4 for signal assignments and Figure 4 for the main lignin structures identified. See Figure 5 for the structure and assignments of the signals of the tricin moiety $(\mathbf{T})$.

carbon, not revealed in HSQC spectra) HMBC data, it is possible to conclude that the structure of the flavone moiety present in the MWL of wheat straw is tricin (5,7,4'-trihydroxy-3',5'-dimethoxyflavone, Figure 5); the ${ }^{1} \mathrm{H}$ and ${ }^{13} \mathrm{C}$ shifts match those published for tricin. ${ }^{50,51}$
The signals appearing in the HSQC spectrum at $\delta_{\mathrm{C}} / \delta_{\mathrm{H}} 94.1 /$ 6.56 and 98.8/6.20 (Figure 3) thus correspond to the $\mathrm{C}_{8}-\mathrm{H}_{8}$ and $\mathrm{C}_{6}-\mathrm{H}_{6}$ correlations, respectively. The HSQC also shows the $\mathrm{C}_{3}-\mathrm{H}_{3}$ correlation at $\delta_{\mathrm{C}} / \delta_{\mathrm{H}} 104.5 / 7.04$, near the $\mathrm{S}_{2,6}$ signal. On the other hand, the phenyl moiety linked at C-2 is of syringyltype, the correlations for $\mathrm{C}_{2^{\prime}}-\mathrm{H}_{2^{\prime}}$ and $\mathrm{C}_{6^{\prime}}-\mathrm{H}_{6^{\prime}}$ being also observed 
Table 4. Assignments of the Lignin ${ }^{13} \mathrm{C}-{ }^{1} \mathrm{H}$ Correlation Peaks in the 2D HSQC Spectra of Wheat Straw and the Isolated $\mathrm{MWL}^{a}$

\begin{tabular}{|c|c|c|}
\hline label & $\delta_{\mathrm{C}} / \delta_{\mathrm{H}}(\mathrm{ppm})$ & assignment \\
\hline $\mathrm{B}_{\beta}$ & $53.1 / 3.43$ & $\begin{array}{l}\mathrm{C}_{\beta}-\mathrm{H}_{\beta} \text { in phenylcoumaran substructures } \\
\quad(\mathbf{B})\end{array}$ \\
\hline $\mathrm{C}_{\beta}$ & $53.5 / 3.05$ & $\mathrm{C}_{\beta}-\mathrm{H}_{\beta}$ in $\beta-\beta^{\prime}$ resinol substructures $(\mathbf{C})$ \\
\hline$-\mathrm{OCH}_{3}$ & $55.6 / 3.73$ & $\mathrm{C}-\mathrm{H}$ in methoxyls \\
\hline $\mathrm{A}_{\gamma}$ & $59.4 / 3.40$ and 3.72 & $\begin{array}{l}\mathrm{C}_{\gamma}-\mathrm{H}_{\gamma} \text { in } \gamma \text {-hydroxylated } \beta-O-4^{\prime} \\
\text { substructures }(\mathbf{A})\end{array}$ \\
\hline $\mathrm{F}_{\beta}$ & $59.5 / 2.75$ & $\mathrm{C}_{\beta}-\mathrm{H}_{\beta}$ in spirodienone substructures $(\mathbf{F})$ \\
\hline $\mathrm{I}_{\gamma}$ & $61.3 / 4.08$ & $\mathrm{C}_{\gamma}-\mathrm{H}_{\gamma}$ in cinnamyl alcohol end-groups $(\mathrm{I})$ \\
\hline $\mathrm{B}_{\gamma}$ & $62.6 / 3.67$ & $\begin{array}{l}\mathrm{C}_{\gamma}-\mathrm{H}_{\gamma} \text { in phenylcoumaran substructures } \\
(\mathbf{B})\end{array}$ \\
\hline $\mathrm{A}_{\gamma}^{\prime}$ & $63.5 / 3.83$ and 4.30 & 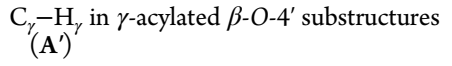 \\
\hline $\mathrm{A}_{\alpha(\mathrm{G})}$ & $70.9 / 4.71$ & $\begin{array}{l}\mathrm{C}_{\alpha}-\mathrm{H}_{\alpha} \text { in } \beta-O-4^{\prime} \text { substructures (A) linked } \\
\text { to a G-unit }\end{array}$ \\
\hline $\mathrm{C}_{\gamma}$ & $71.0 / 3.81$ and 4.17 & $\mathrm{C}_{\gamma}-\mathrm{H}_{\gamma}$ in $\beta-\beta^{\prime}$ resinol substructures $(\mathbf{C})$ \\
\hline $\mathrm{A}_{\alpha(\mathrm{S})}$ & $71.8 / 4.83$ & $\begin{array}{l}\mathrm{C}_{\alpha}-\mathrm{H}_{\alpha} \text { in } \beta-O-4^{\prime} \text { substructures (A) linked } \\
\text { to a S-unit }\end{array}$ \\
\hline $\mathrm{E}_{\alpha}$ & $79.5 / 5.50$ & $\mathrm{C}_{\alpha}-\mathrm{H}_{\alpha}$ in $\alpha-O-4^{\prime}$ substructures $(\mathrm{E})$ \\
\hline $\mathrm{A}_{\beta(\mathrm{G})}^{\prime}$ & $80.8 / 4.52$ & $\begin{array}{l}\mathrm{C}_{\beta}-\mathrm{H}_{\beta} \text { in } \gamma \text {-acylated } \beta \text {-O-O' substructures } \\
\text { linked to a G-unit }\left(\mathbf{A}^{\prime}\right)\end{array}$ \\
\hline $\mathrm{F}_{\alpha}$ & $81.2 / 5.01$ & $\mathrm{C}_{\alpha}-\mathrm{H}_{\alpha}$ in spirodienone substructures $(\mathbf{F})$ \\
\hline $\mathrm{A}_{\mathrm{ox} \beta}$ & $82.7 / 5.12$ & $\begin{array}{l}\mathrm{C}_{\beta}-\mathrm{H}_{\beta} \text { in } \alpha \text {-oxidized } \beta \text {-O- } 4^{\prime} \text { substructures } \\
\left(\mathrm{A}_{\mathrm{ox}}\right)\end{array}$ \\
\hline $\mathrm{A}_{\beta(\mathrm{H})}$ & $82.9 / 4.48$ & $\begin{array}{l}\mathrm{C}_{\beta}-\mathrm{H}_{\beta} \text { in } \beta-O-4^{\prime} \text { substructures (A) linked } \\
\text { to a } \mathrm{H} \text {-unit }\end{array}$ \\
\hline $\mathrm{D}_{\alpha}$ & $83.3 / 4.81$ & $\begin{array}{l}\mathrm{C}_{\alpha}-\mathrm{H}_{\alpha} \text { in dibenzodioxocin substructures } \\
\text { (D) }\end{array}$ \\
\hline $\mathrm{A}_{\beta(\mathrm{G})}$ & $83.4 / 4.27$ & $\begin{array}{l}\mathrm{C}_{\beta}-\mathrm{H}_{\beta} \text { in } \beta-O-4^{\prime} \text { substructures }(\mathrm{A}) \text { linked } \\
\text { to a } \mathrm{G} \text { unit }\end{array}$ \\
\hline $\mathrm{C}_{\alpha}$ & $84.8 / 4.65$ & $\mathrm{C}_{\alpha}-\mathrm{H}_{\alpha}$ in $\beta-\beta^{\prime}$ resinol substructures $(\mathbf{C})$ \\
\hline $\mathrm{F}_{\alpha^{\prime}}$ & $84.6 / 4.75$ & $\mathrm{C}_{\alpha^{\prime}}-\mathrm{H}_{\alpha^{\prime}}$ in spirodienone substructures $(\mathbf{F})$ \\
\hline $\mathrm{D}_{\beta}$ & $85.3 / 3.85$ & $\begin{array}{l}\mathrm{C}_{\beta}-\mathrm{H}_{\beta} \text { in dibenzodioxocin substructures } \\
\text { (D) }\end{array}$ \\
\hline $\mathrm{A}_{\beta(\mathrm{S})}$ & $85.9 / 4.10$ & $\begin{array}{l}\mathrm{C}_{\beta}-\mathrm{H}_{\beta} \text { in } \beta-O-4^{\prime} \text { substructures linked (A) } \\
\text { to a } \mathrm{S} \text { unit }\end{array}$ \\
\hline $\mathrm{B}_{\alpha}$ & $86.8 / 5.43$ & $\begin{array}{l}\mathrm{C}_{\alpha}-\mathrm{H}_{\alpha} \text { in phenylcoumaran substructures } \\
\text { (B) }\end{array}$ \\
\hline$S_{2,6}$ & $103.8 / 6.69$ & $\begin{array}{l}\mathrm{C}_{2}-\mathrm{H}_{2} \text { and } \mathrm{C}_{6}-\mathrm{H}_{6} \text { in etherified syringyl } \\
\text { units (S) }\end{array}$ \\
\hline $\mathrm{G}_{2}$ & $110.9 / 6.99$ & $\mathrm{C}_{2}-\mathrm{H}_{2}$ in guaiacyl units $(\mathbf{G})$ \\
\hline $\mathrm{Fer}_{2}$ & $111.0 / 7.32$ & $\mathrm{C}_{2}-\mathrm{H}_{2}$ in ferulate (FA) \\
\hline $\begin{array}{l}\mathrm{PCA}_{\beta} \text { and } \\
\mathrm{FA}_{\beta}\end{array}$ & $113.5 / 6.27$ & $\begin{array}{l}\mathrm{C}_{\beta}-\mathrm{H}_{\beta} \text { in } p \text {-coumarate (PCA) and } \\
\text { ferulate (FA) }\end{array}$ \\
\hline $\mathrm{G}_{5} / \mathrm{G}_{6}$ & $\begin{array}{l}114.9 / 6.72 \text { and } 6.94 \\
118.7 / 6.77\end{array}$ & $\mathrm{C}_{5}-\mathrm{H}_{5}$ and $\mathrm{C}_{6}-\mathrm{H}_{6}$ in guaiacyl units $(\mathbf{G})$ \\
\hline $\mathrm{PCA}_{3,5}$ & $115.5 / 6.77$ & $\mathrm{C}_{3}-\mathrm{H}_{3}$ and $\mathrm{C}_{5}-\mathrm{H}_{5}$ in $p$-coumarate (PCA) \\
\hline $\mathrm{FA}_{6}$ & $123.2 / 7.15$ & $\mathrm{C}_{6}-\mathrm{H}_{6}$ in ferulate $(\mathbf{F A})$ \\
\hline $\mathrm{J}_{\beta}$ & $126.3 / 6.76$ & $\begin{array}{l}\mathrm{C}_{\beta}-\mathrm{H}_{\beta} \text { in cinnamyl aldehyde end-groups } \\
(\mathrm{J})\end{array}$ \\
\hline $\mathrm{H}_{2,6}$ & $127.8 / 7.22$ & $\mathrm{C}_{2,6}-\mathrm{H}_{2,6}$ in $p$-hydroxyphenyl units $(\mathbf{H})$ \\
\hline $\mathrm{I}_{\beta}$ & $128.4 / 6.23$ & $\begin{array}{l}\mathrm{C}_{\beta}-\mathrm{H}_{\beta} \text { in cinnamyl alcohol end-groups } \\
(\mathrm{I})\end{array}$ \\
\hline $\mathrm{I}_{\alpha}$ & $128.4 / 6.44$ & $\begin{array}{l}\mathrm{C}_{\alpha}-\mathrm{H}_{\alpha} \text { in cinnamyl alcohol end-groups } \\
\text { (I) }\end{array}$ \\
\hline $\mathrm{PCA}_{2,6}$ & $130.1 / 7.45$ & $\mathrm{C}_{2}-\mathrm{H}_{2}$ and $\mathrm{C}_{6}-\mathrm{H}_{6}$ in $p$-coumarate (PCA) \\
\hline $\begin{array}{l}\mathrm{PCA}_{\alpha} \text { and } \\
\mathrm{FA}_{\alpha}\end{array}$ & $144.7 / 7.41$ & $\begin{array}{l}\mathrm{C}_{\alpha}-\mathrm{H}_{\alpha} \text { in } p \text {-coumarate (PCA) and } \\
\text { ferulate (FA) }\end{array}$ \\
\hline $\mathrm{J}_{\alpha}$ & $153.4 / 7.61$ & $\begin{array}{l}\mathrm{C}_{\alpha}-\mathrm{H}_{\alpha} \text { in cinnamyl aldehyde end-groups } \\
\quad(\mathrm{J})\end{array}$ \\
\hline
\end{tabular}

${ }^{a}$ Signals were assigned by comparison with the literature. ${ }^{26-35}$

in the HSQC spectrum at $\delta_{\mathrm{C}} / \delta_{\mathrm{H}} 103.9 / 7.31$. Tricin has two phenolic hydroxyls at C-5 and C-7 of the chroman-4-one skeleton, with diagnostic phenolic proton chemical shifts that are readily apparent in the $\mathrm{HMBC}$; DMSO is a solvent that limits proton transfer, ${ }^{34}$ so the $\mathrm{H}$-bonded $\mathrm{C} 5-\mathrm{OH}$ proton signal at $12.86 \mathrm{ppm}$ and the $\mathrm{C} 7-\mathrm{OH}$ proton signal at $10.88 \mathrm{ppm}$ are sharp in this solvent and therefore produce good correlations in longrange ${ }^{13} \mathrm{C}-{ }^{1} \mathrm{H}$ correlation spectra. In addition, the absence of the signals for the phenolic 4'-OH of tricin in the HMBC proton indicates that it is not free. Therefore, incorporation of tricin into the lignin network through 4-O- $\beta$ ether linkages, as occurs with the flavonolignans (see below), is indicated. In fact, a signal for the correlation of the tricin $\mathrm{C}^{\prime}$ ' carbon (at $139.5 \mathrm{ppm}$ ) and a proton at the $\beta$-position of a G-unit at $4.28 \mathrm{ppm}$ was clearly observed in the HMBC spectrum (see Supporting Information), providing evidence for this incorporation.

Tricin is widely distributed in grasses, including wheat, rice, barley, sorghum, and maize, ${ }^{52}$ and can occur in either free or conjugated form. Tricin can form flavonolignan derivatives with a tricin skeleton linked to a phenylpropanoid ( $p$-hydroxyphenyl or guaiacyl) moiety through a $\beta-O-4$ bond, such as tricin $4{ }^{\prime}-O-\beta$ guaiacylglycerol ether, among others. ${ }^{50,51}$ Flavones (as all other flavanoids/flavonoids) are metabolic hybrids as they are derived from a combination of the shikimate-derived phenylpropanoid and the acetate/malonate-derived polyketide pathways. Since polyphenols are formed in lignified regions by oxidative coupling, incorporation into the lignin structure is a possibility. In fact, other related benzene diols and triols, such as the flavanols epicatechin, epigallocatechin, or epigallocatechin gallate, although they are not known in actual plant cell walls, have been shown to produce lignin copolymers with normal monolignols. ${ }^{53}$ The presence (or otherwise) in lignins of components from other pathways is of significant interest. It has never been demonstrated, for example, that lignans, dimers, and higher oligomers that also arise from radical coupling of monolignols, become incorporated into lignins. ${ }^{9,54-56}$ Lignans are produced under proteinaceous control such that they are always (at least partially) optically active. ${ }^{57}$ Lignins are completely racemic; ${ }^{55}$ no components excised from lignins have ever been shown to be optically active, so the lignin polymer and the lignan "extractives" are assumed to be independently produced in time and space. For this reason, this observation along with the evidence presented here that a flavone, tricin, is integrally incorporated into lignin, if validated completely, is a new phenomenon with rather profound implications. It implies that the monomer is exported to the cell wall where it undergoes radical coupling reactions with monolignols, or at least with the primary monolignol coniferyl alcohol, and becomes part of the lignin polymer. The occurrence of tricin in the MWL of wheat straw seems to be evidence for this incorporation. At the very least, then, this observation will require further recognition of the malleability of lignification and perhaps another addition to the list of phenolics that must be considered to be "lignin monomers". 58

Quantitation. The relative abundances of the main lignin interunit linkages and end-groups, as well as the percentage of $\gamma$ acylation, the molar abundances of the different lignin units $(H$, $\mathrm{G}$, and $\mathrm{S}$ ), $p$-coumarates, and ferulates, and the molar $\mathrm{S} / \mathrm{G}$ ratios of the lignin in wheat straw, estimated from volume integration of contours in the HSQC spectra, ${ }^{24,34,35}$ are shown in Table 5. Similarly as observed by Py-GC/MS, the abundance of ferulate is lower in the isolated MWL than in the corresponding whole cell wall, confirming that ferulate is mostly attached to polysaccharides, whereas $p$-coumarate is predominantly attached to lignin. In addition, the $S / G$ ratio estimated from the HSQC (S/G $0.5)$ is similar to that estimated by analytical pyrolysis. The 
<smiles>COc1cc(C)cc(C(O)C(Oc2c(C)cc(I)cc2OC)[Te]O)c1</smiles>

A<smiles>[R]C(=O)O[CH][C@@H](Oc1c(C)cc([Z])cc1OC)[C@@H](O)c1cc(C)c(OCC)c(OC)c1</smiles>

$A^{\prime}$<smiles>COc1cc(C(=O)C(Oc2c(C)cc(C)cc2C)[Te]O)cc(C)c1OC</smiles>

A ox<smiles>COc1cc(OC)c2c(c1)[C@H](CO)C(c1cc(C)c(OC)c(OC)c1)O2</smiles>

B<smiles>CCOc1c(C)cc([C@@H]2O[C][C@@H]3[C@@H](c4cc(C)c(OCC)c(OC)c4)O[I][C@H]23)cc1OC</smiles>

C<smiles>CCOc1c(C)cc(C2Oc3c(OC)cc(C)cc3-c3cc(C)cc(OC)c3OC(CO)C2CO)cc1OC</smiles>

D<smiles>CCOc1c(C)cc(C(Oc2c(C)cc(C)cc2OC)C(CO)Oc2c(C)cc(CC)cc2OC)cc1OC</smiles>

E<smiles>[3H]C(O)C1OC(c2cc(C)c(OCC)c(OC)c2)C(C=C2C=C(C)C(=O)C(OC)=C2)C1CO</smiles><smiles>CCOC(=O)C=Cc1ccc(OCC)c(OC)c1</smiles>

FA<smiles>COc1ccc(C(C)O)cc1</smiles>

H
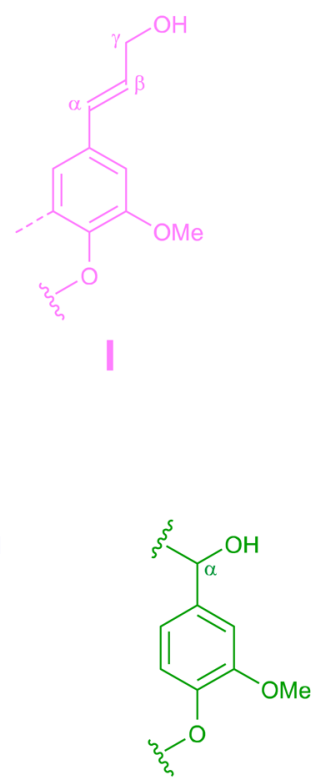

G<smiles>CCOc1c(C)cc(C=CC=O)cc1OC</smiles><smiles>CCOC(=O)C=Cc1ccc(O)cc1</smiles>

PCA

Figure 4. Main structures present in the lignins of wheat straw: (A) $\beta$-O-4' alkyl-aryl ethers; $\left(\mathbf{A}^{\prime}\right) \beta-O-4^{\prime}$ alkyl-aryl ethers with acylated $\gamma$-OH; $\left(\mathbf{A}_{\text {ox }}\right) \mathrm{C}_{\alpha^{-}}$ oxidized $\beta$-O-4' structures; (B) phenylcoumarans; (C) resinols; (D) dibenzodioxocins; (E) $\alpha$, $\beta$-diaryl ethers; (F) spirodienones; (I) cinnamyl alcohol end-groups; (J) cinnamyl aldehyde end-groups; (PCA) p-coumarates; (FA) ferulates; (H) p-hydroxyphenyl units; (G) guaiacyl units; (S) syringyl units.

relative abundances of $p$-coumarate and $\mathrm{H}$ lignin units are probably more realistic than those provided by Py-GC/MS and Py-TMAH analyses, as Py-GC/MS does not distinguish between both types of structures, as already discussed, and Py-TMAH overestimates the esters, including $p$-coumarate residues, because of the production of a single vinyl-phenol from each with high pyrolytic efficiency. However, the end-groups, estimated as $\sim 10 \%$ of the total lignin linkages (with similar amounts of cinnamyl alcohols and aldehydes), are overestimated in HSQC spectra because of their longer relaxation than the bulk polymer (see Materials and Methods). The data indicated that the structure of the lignins is mostly made up of $\beta-O-4^{\prime}$ linkages (accounting for $75 \%$ of all the interunit linkages), followed by phenylcoumarans (11\%) and lower amounts of resinols, dibenzodioxocins, $\alpha, \beta$-diaryl ethers, and spirodienones. These results sharply contrast with the data reported by Banoub et al. ${ }^{15}$ that indicated that wheat straw lignin was made up almost 
Table 5. Structural Characteristics (Lignin Interunit Linkages, End-Groups, $\boldsymbol{\gamma}$-Acylation, Aromatic Units and S/G Ratio, Cinnamate Content, and $p$-Coumarate/Ferulate Ratio) from Integration of ${ }^{13} \mathrm{C}-{ }^{1} \mathrm{H}$ Correlation Peaks in the HSQC Spectra of the Wheat Straw and the Isolated MWL

\begin{tabular}{|c|c|c|}
\hline & \multicolumn{2}{|c|}{ wheat straw } \\
\hline & cell walls & MWL \\
\hline \multicolumn{3}{|l|}{ lignin interunit linkages (\%) } \\
\hline$\beta-O-4^{\prime}$ aryl ethers $\left(\mathbf{A} / \mathbf{A}^{\prime}\right)$ & & 75 \\
\hline$\alpha$-oxidized $\beta$-O- $4^{\prime}$ aryl ethers $\left(\mathbf{A}_{\mathbf{o x}}\right)$ & & 2 \\
\hline phenylcoumarans (B) & & 11 \\
\hline resinols $(\mathbf{C})$ & & 4 \\
\hline dibenzodioxocins (D) & & 3 \\
\hline$\alpha, \beta$-diaryl ethers $(\mathbf{E})$ & & 2 \\
\hline spirodienones $(\mathbf{F})$ & & 3 \\
\hline total & & 100 \\
\hline \multicolumn{3}{|l|}{ lignin end-groups ${ }^{a}$} \\
\hline cinnamyl alcohol end-groups (I) & & 4 \\
\hline cinnamaldehyde end-groups $(\mathrm{J})$ & & 4 \\
\hline lignin side-chain $\gamma$-acylation (\%) & & 10 \\
\hline \multicolumn{3}{|l|}{ lignin aromatic units ${ }^{b}$} \\
\hline $\mathrm{H}(\%)$ & 6 & 6 \\
\hline G (\%) & 64 & 64 \\
\hline$S(\%)$ & 30 & 30 \\
\hline $\mathrm{S} / \mathrm{G}$ ratio & 0.5 & 0.5 \\
\hline \multicolumn{3}{|l|}{$p$-hydroxycinnamates ${ }^{c}$} \\
\hline$p$-coumarates $(\%)$ & 4 & 4 \\
\hline ferulates (\%) & 11 & 2 \\
\hline$p$-coumarates/ferulates ratio & 0.4 & 2.0 \\
\hline
\end{tabular}

${ }^{a}$ Expressed as a fraction of the total lignin interunit linkage types A-F. ${ }^{b}$ Molar percentages $(\mathrm{H}+\mathrm{G}+\mathrm{S}=100) \cdot{ }^{c} p$-Coumarate and ferulate molar contents as percentages of lignin content $(H+G+S)$.

exclusively of repeating phenylcoumaran units, an occurrence that would be novel indeed.

Resolving the Lignin Acylation Anomaly. The fact that the side chain of the lignin in wheat straw is partially acylated at the $\gamma$ $\mathrm{OH}$, together with the presence of significant amounts of $p$ coumarate moieties ( $4 \%$ with respect to lignin), which are known to acylate the $\gamma-\mathrm{OH}$ of the lignin side chain in many plants, and particularly in grasses, ${ }^{10,21,26,31,59}$ led other authors to conclude that $p$-coumarates also acylate the $\gamma-\mathrm{OH}$ in the lignin of wheat straw, ${ }^{11}$ although no direct evidence of this linkage was provided. The HSQC spectrum only indicates that the lignin in wheat straw is partially acylated at the $\gamma$-position, but cannot provide information on the nature of the acyl group. Additional analyses are therefore needed to confirm whether $p$-coumarates (or other groups) acylate the $\gamma-\mathrm{OH}$ of the lignin side chain. For this purpose, we performed HMBC experiments, again correlating protons with carbons separated by 2 or 3 bonds, that can give important information about the connectivity of the ester moiety to the lignin skeleton. ${ }^{26}$ Figure 6 shows the section of the HMBC spectrum of wheat straw MWL for the correlations of the carbonyl carbons of the different groups acylating the lignin $\gamma$ $\mathrm{OH}$. Two distinct carbonyl carbons were observed in this region of the HMBC spectrum, at $166.0 \mathrm{ppm}$ for $p$-coumarates and $169.8 \mathrm{ppm}$ for acetates, Figure 6B. The correlations of the carbonyl carbon at $166.0 \mathrm{ppm}$ with the $\alpha$ - and $\beta$-protons of $p$ coumarate esters (at 7.41 and $6.27 \mathrm{ppm}$ ) confirm that they belong to the $p$-coumarate esters. The correlations of this carbonyl carbon with several protons in the range 4.0-4.8 ppm conclusively demonstrate that $p$-coumarate is acylating the $\gamma$ -

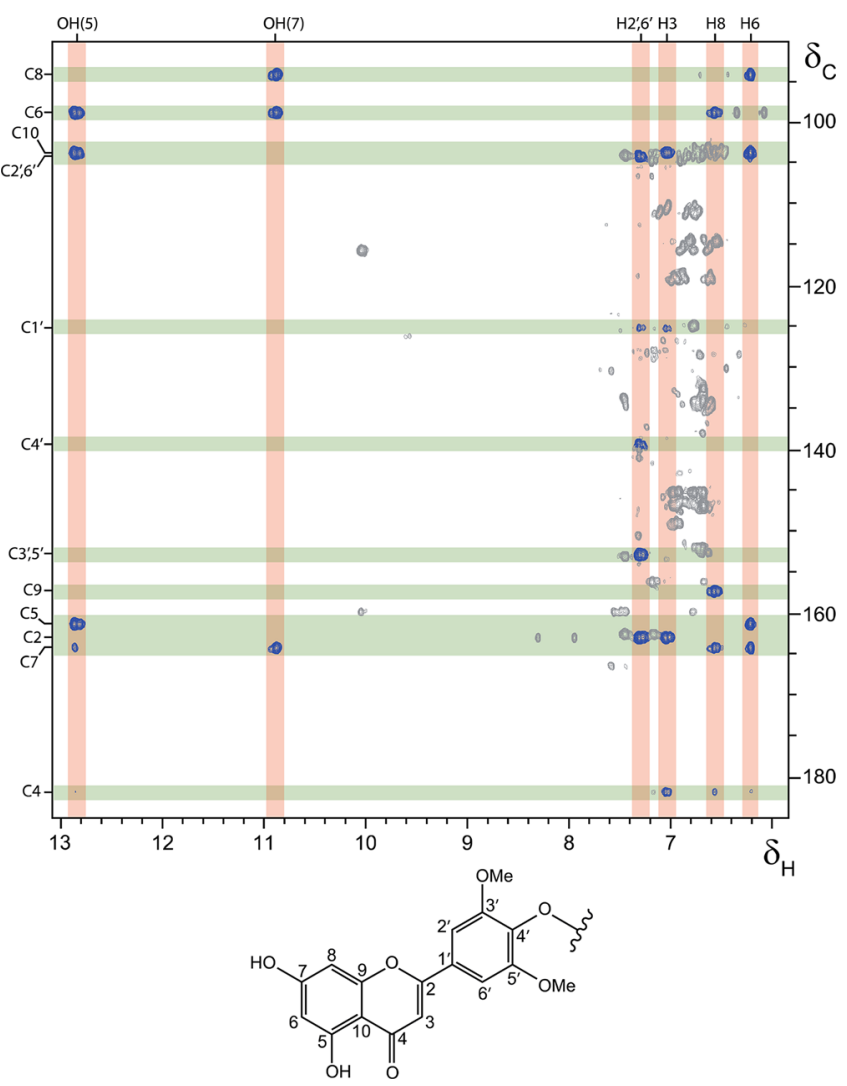

Figure 5. Partial HMBC spectrum $\left(\delta_{\mathrm{C}} / \delta_{\mathrm{H}} 90-185 / 6.0-13.0\right)$ of wheat straw MWL showing the main correlations and the structure of tricin (5,7,4'-trihydroxy-3',5'-dimethoxyflavone) units in the lignin.

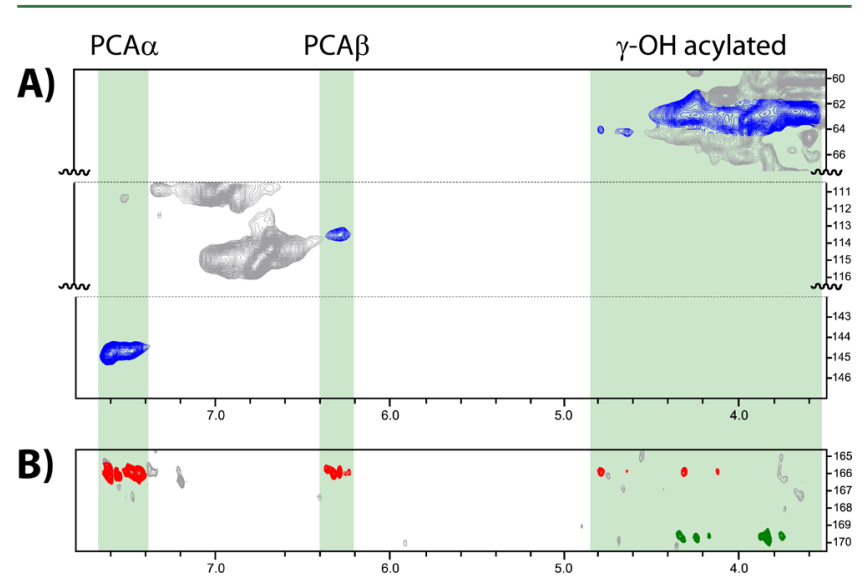

Figure 6. Section of the HMBC spectrum $\left(\delta_{\mathrm{C}} / \delta_{\mathrm{H}} 164-171 / 3.5-7.8\right)$ of wheat straw MWL showing the main correlations for the carbonyl carbons of the groups ( $p$-coumarates and acetates) acylating the $\gamma$ position of the lignin side chain (B). Appropriate sections of the HSQC spectrum showing the $\mathrm{C}_{\gamma}-\mathrm{H}_{\gamma}$ correlations of the acylated lignin $\gamma$ carbon $\left(\delta_{\mathrm{C}} 60-66\right)$ and the $\mathrm{C}_{\alpha}-\mathrm{H}_{\alpha}$ and $\mathrm{C}_{\beta}-\mathrm{H}_{\beta}$ correlations of $p$ coumarates $\left(\delta_{\mathrm{C}} 111-116\right.$ and $142-147$, respectively), are also depicted (A).

position of the lignin side chains, as also occurs in other grasses, ${ }^{10,21,26,31,59}$ although the intensity of these signals is low as the $p$-coumarate level is only $4 \%$ here (and HMBC spectra are not quantitative). In addition, the HBMC spectrum also showed the correlations of the carbonyl carbon at 169.8 for acetate groups attached to the lignin network. As expected, there was a strong correlation with the acetate methyl group at $1.88 \mathrm{ppm}$ 
(not shown). The correlations of this carbonyl carbon with the protons in the range 3.6-4.4 ppm indicate that acetates are also acylating the $\gamma$-OH of the lignin side chain. As with $p$-coumarates, several correlations were also observed in this region suggesting, beyond the fact that there are two usually distinct $\gamma$-proton shifts, the involvement of both acetates and $p$-coumarates at the $\gamma$ positions of different lignin substructures. Acetates have also been previously found acylating the $\gamma-\mathrm{OH}$ in the lignins of many plants, including grasses. ${ }^{21,31,39,40,60,61}$ Further details regarding the lignin acylation in wheat, via $p$-coumarate and acetate, is provided by additional experiments below.

Derivatization Followed by Reductive Cleavage (DFRC and DFRC') of Wheat Straw MWL. Additional information regarding the acylation of the $\gamma-\mathrm{OH}$ of the lignin side chain can be obtained from DFRC, a degradation method that cleaves $\alpha$ - and $\beta$-ether linkages in the lignin polymer leaving $\gamma$-esters intact. ${ }^{36-38}$

The chromatogram of the DFRC degradation products of the MWL isolated from the wheat straw is shown in Figure 7 (top).
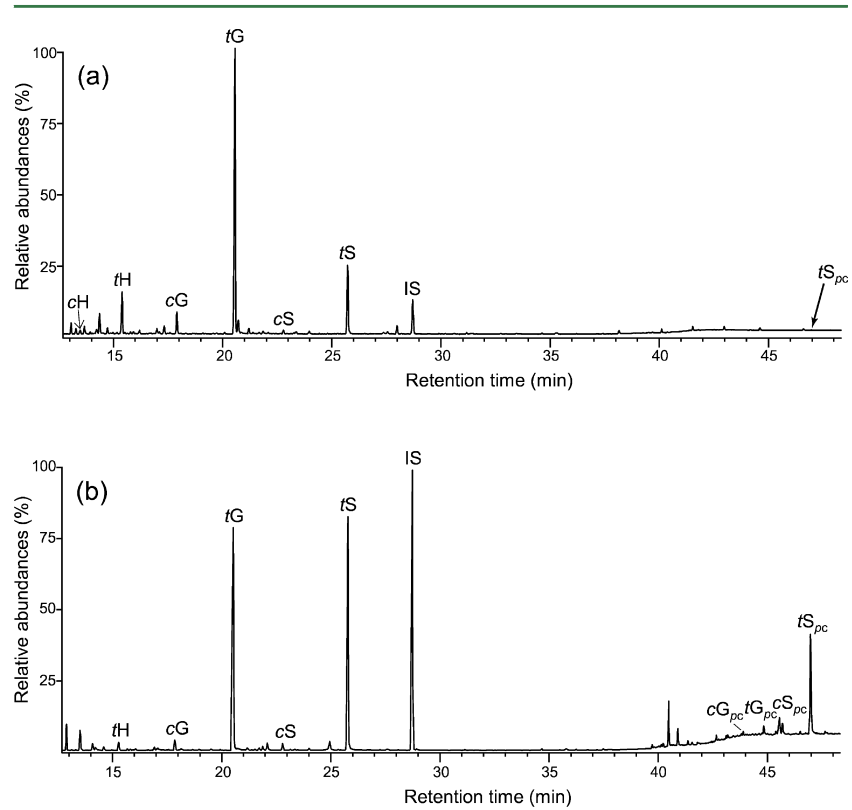

Figure 7. Chromatograms (GC-TIC) of the DFRC degradation products from the MWL isolated from wheat straw (a), and the MWL isolated from elephant grass cortex (b), that is shown here only for comparison. $c \mathrm{G}, t \mathrm{G}, c \mathrm{~S}$, and $t \mathrm{~S}$ are the normal cis- and trans-coniferyl and -sinapyl alcohol (guaiacyl and syringyl) monomers (as their acetate derivatives). Note the absence of cis- and trans-coniferyl and -sinapyl $p$ coumarates $\left(c \mathrm{G}_{p c}\right.$ and $t \mathrm{G}_{p c}$ and $c S_{p c}$ and $\left.t \mathrm{~S}_{p c}\right)$ in the MWL from wheat straw, and which are present in elephant grass.

The lignin released the cis-and trans-isomers of $p$-hydroxyphenyl ( $c \mathrm{H}$ and $t \mathrm{H}$ ), guaiacyl ( $c \mathrm{G}$ and $t \mathrm{G}$ ), and syringyl ( $c \mathrm{~S}$ and $t \mathrm{~S})$ lignin monomers (as their acetylated derivatives) arising from normal, non- $\gamma$-p-coumaroylated $\beta$-ethers in lignin. Significant amounts of the monolignol $p$-coumarate conjugates were anticipated to be released, if $p$-coumarates acylate the $\gamma$-OH in the lignin, upon DFRC. However, and unexpectedly, only traces of $\gamma-p$ coumaroylated syringyl $\left(c S_{p c}\right.$ and $\left.t S_{p c}\right)$ monomers could be detected in the chromatogram ( $\sim 1 \%$ of $S$ units, as shown in Table 6), despite the decent amounts of $p$-coumarates (4\% with respect to the total aromatic units) present in this lignin, and the fact that $p$-coumarates are acylating the $\gamma$-carbon, as observed by 2D-NMR. A chromatogram of the DFRC degradation products of the MWL isolated from elephant grass (Figure 7, bottom), that releases significant amounts of sinapyl $p$-coumarate, is shown for comparison to emphasize the stark difference with wheat straw. We have to stress here that both the DFRC degradation and the GC-MS analysis were repeated several times with increasing amounts of sample for the DFRC degradation, and increasing product concentrations for the GC-MS analyses, and we always failed to detect higher amounts of the conjugate $S_{\mathrm{pc}}$. No traces of $\gamma$-p-coumaroylated guaiacyl $\left(c \mathrm{G}_{p c}\right.$ and $\left.t \mathrm{G}_{p c}\right)$ lignin units could be found, despite this lignin's being enriched in G-units. This finding clearly indicates that, in wheat straw, $p$-coumarate groups are attached to the lignin $\gamma-\mathrm{OH}$ in $\beta$-ether structures only to a very low extent. As NMR indicated that some $p$-coumarates are indeed attached to the $\gamma-\mathrm{OH}$, the only conclusion is that they are largely in other (i.e., non- $\beta$-ether) lignin substructures.

Acetate groups, on the other hand, also widely occur acylating the $\gamma-\mathrm{OH}$ in the lignin of many plants, including grasses, palms, and (at trace levels) most hardwoods, ${ }^{31,39,40,60}$ and their occurrence in the lignin of wheat straw was also clearly observed in the HMBC spectrum of the MWL, as noted above. The original DFRC degradation method, however, does not allow the analysis of natively acetylated lignin because the degradation products are acetylated during the procedure, but with appropriate modification of the protocol by substituting acetylating reagents with propionylating ones (in the so-called DFRC' method) it is possible to obtain information about the occurrence of native acetates in lignin. ${ }^{31,39,40}$

The chromatogram of the DFRC' degradation products released from the wheat straw MWL is shown in Figure 8. The lignin released the cis-and trans-isomers of $p$-hydroxyphenyl $(\mathrm{cH}$ and $t \mathrm{H}$ ), guaiacyl ( $c \mathrm{G}$ and $t \mathrm{G})$, and syringyl $(c S$ and $t S)$ lignin monomers (as their propionylated derivatives) arising from normal, nonacetylated $\gamma$-units in lignin. Interestingly, the presence of $\gamma$-acetylated guaiacyl $\left(c \mathrm{G}_{\mathrm{ac}}\right.$ and $\left.t \mathrm{G}_{\mathrm{ac}}\right)$ and syringyl $\left(t S_{\mathrm{ac}}\right)$ lignin units could also be clearly observed in the chromatogram, and confirms the occurrence of native acetylation at the $\gamma$-carbon of the lignin side chain of wheat straw. The results from the DFRC and DFRC' analyses of the MWL selected for this study, namely, the molar yields of the released monomers, the percentages of naturally acetylated guaiacyl $\left(\% \mathrm{G}_{\mathrm{ac}}\right)$ and syringyl $\left(\% \mathrm{~S}_{\mathrm{ac}}\right)$ lignin moieties, and the $\mathrm{S} / \mathrm{G}$ ratio, are presented in Table 6 . The analyses indicated that up to $12 \%$ of the

Table 6. Abundance (Molar Yields) of the DFRC and DFRC' Degradation Monomers of the MWL Isolated from Wheat Straw and Relative Abundances of the Different Acylated Lignin Monomers

\begin{tabular}{|c|c|c|c|c|c|c|c|c|c|c|c|c|}
\hline & \multicolumn{12}{|c|}{ monomers $(\mu \mathrm{mol} / \mathrm{g}$ lignin $)$} \\
\hline & $\mathrm{H}$ & $\mathrm{G}$ & $\mathrm{G}_{\mathrm{ac}}$ & $\mathrm{G}_{\mathrm{p} c}$ & $S$ & $\mathrm{~S}_{\mathrm{ac}}$ & $\mathrm{S}_{p c}$ & $\% \mathrm{G}_{\mathrm{ac}}{ }^{a}$ & $\% \mathrm{G}_{p c}{ }^{b}$ & $\% \mathrm{~S}_{\mathrm{ac}}{ }^{c}$ & $\% \mathrm{~S}_{p c}{ }^{d}$ & $\mathrm{~S} / \mathrm{G}$ \\
\hline MWL wheat straw & 67 & 386 & 52 & 0 & 196 & 2 & 2 & 12 & 0 & 1 & 1 & 0.5 \\
\hline
\end{tabular}

$a_{\%} G_{a c}$ is the percentage of acetylated $G$ units $\left(G_{a c}\right)$ with respect to the total $G$ units $\left(G, G_{a c}, G_{p c}\right)$. ${ }^{b} \% G_{p c}$ is the percentage of $p$-coumaroylated $G$ units $\left(G_{p c}\right)$ with respect to the total $G$ units $\left(G, G_{a c}, G_{p c}\right) .{ }^{c} \% S_{a c}$ is the percentage of acetylated $S$ units $\left(S_{a c}\right)$ with respect to the total $S$ units $\left(S, S_{a c}\right.$ $\left.S_{p c}\right) .{ }^{d} \% S_{p c}$ is the percentage of $p$-coumaroylated $S$ units $\left(S_{p c}\right)$ with respect to the total $S$ units $\left(S, S_{a c} S_{p c}\right)$. 


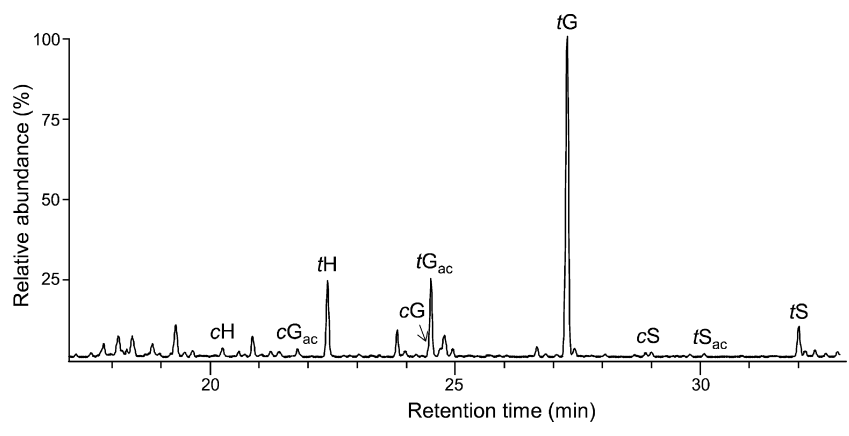

Figure 8. Chromatogram (GC-TIC) of the DFRC' degradation products from the MWL isolated from wheat straw. $c \mathrm{G}, t \mathrm{G}, c \mathrm{~S}$, and $t S$ are the normal cis- and trans-coniferyl and sinapyl alcohol (guaiacyl and syringyl) monomers (as their dipropionylated derivatives). $c \mathrm{G}_{\mathrm{ac}} t \mathrm{G}_{\mathrm{ac}}$ $c \mathrm{~S}_{\mathrm{ac}}$ and $t \mathrm{~S}_{\mathrm{ac}}$ are the natively $\gamma$-acetylated cis- and trans-coniferyl and -sinapyl alcohol (guaiacyl and syringyl) monomers (as their phenolpropionylated derivatives).

releasable G-lignin units are acetylated, while only $1 \%$ of the total S-lignin units are acetylated. It is interesting to note that in the lignin of most plants in which acetylated lignins have been characterized, such as kenaf, sisal, abaca, or curaua, $\gamma$-acetates have always been preferentially attached to S-lignin units; ${ }^{31,40,60}$ however, a preferential $\gamma$-acetylation of G-lignin units has been observed in other grasses, such as bamboo and elephant grass. ${ }^{21,40}$ Previous papers describing the structure of the lignin in wheat straw failed to detect the important levels of acetate groups acylating the lignin $\gamma-\mathrm{OH}$; the acylation was previously attributed exclusively to $p$-coumarates. It is now clear that, in the lignin of wheat straw, the nature and extent of $\gamma$-acylation $(\sim 10 \%$ as observed in the HSQC) is mostly due to acetates, at least those in $\beta$-ether units (that are quantifiable by DFRC or DFRC'). As the mechanism for lignin $\gamma$-acylation involves coupling and crosscoupling reactions of previously acylated monolignols, ${ }^{61}$ it is evident that, in the lignin of wheat straw, the most important monolignol conjugate would be coniferyl acetate.

With respect to $p$-coumarates, if they are attached to the $\gamma$ carbon on the lignin in wheat straw, as suggested by $2 \mathrm{D}-\mathrm{NMR}$, the question is why are they not better represented on $\beta$-ether units in lignins? To these authors, it seems that the only reasonable hypothesis is that wheat differs from corn and other grasses in two respects. First, the acylation is largely on guaiacyl units and therefore derives from acylated coniferyl alcohol conjugates. We already see this evidence for the acetylated monolignols, where coniferyl acetate is significantly favored over sinapyl acetate, as evidenced by the DFRC' data (Table 6). Second, one has to contend, and it is a possible consequence of the coniferyl alcohol (vs sinapyl alcohol) acylation, that these conjugates are present early during lignification. It has been nicely established, by autoradiographic methods, ${ }^{62}$ that sinapyl alcohol incorporation into cell walls occurs later during wall development. It is therefore reasonable that sinapyl $p$-coumarate, the major monolignol $p$-coumarate conjugate in corn, for example, would also enter the wall later during development. There have been no studies on the temporal aspects of monolignol conjugates in lignification, but if coniferyl $p$ coumarate was sent to the wall early during lignification, it would be more heavily involved in monolignol (conjugate) dimerization events (rather than chain extension), events that produce only low levels of $\beta$-ether coupling. Thus, the $p$ coumarate would be involved preferentially in $\beta-\beta$ - and $\beta-5$ coupled products, and also in cinnamyl alcohol end-groups, which do not show up in DFRC but in which the $\gamma-\mathrm{C} / \mathrm{H}$ correlations in HSQC spectra remain typical of those from acylated $\gamma$-OHs. This kind of coupling would also be more favored in the so-called bulk vs endwise coupling mode, and, as noted above, there is evidence in the spectra of lignins from wheat here that such bulk coupling is occurring. As noted above, the $\alpha, \beta$-diaryl ethers (E) found in the wheat lignin (Figure 3, top right) are common in synthetic lignins but are rarely seen in natural lignins where the conditions of slow diffusion of monomers (and radicals) are more conducive toward endwise coupling. The currently best hypothesis, then, is that coniferyl $p$ coumarate (rather than sinapyl $p$-coumarate) is the major $p$ coumarate conjugate destined for wheat lignification (just as coniferyl acetate is) and that its export to the wall is early during development such that condensed structures rather than $\beta$-ethers (that can be quantified via ether-cleaving reactions such as those in the DFRC method) are acylated by $p$-coumarate. Establishing the validity of this hypothesis is therefore nontrivial and multifaceted, but will hopefully be the subject of further investigations along with a more careful evaluation, as outlined here, of the exact nature and distribution of lignin acylation in a variety of plant materials.

In conclusion, the lignin from wheat straw has been characterized by different analytical methods that indicated that it is an H:G:S lignin, with a strong predominance of G-lignin units (S/G 0.5), and with some amounts of associated $p$ coumarates and ferulates. Our data indicated that in wheat straw ferulates are mostly attached to carbohydrates (although radical coupling into lignins is complex and difficult to detect), while $p$ coumarates are predominantly attached to the lignin. 2D-NMR indicated that the main lignin interunit linkages are $\beta-O-4^{\prime}$ alkylaryl ethers, followed by phenylcoumarans and minor amounts of resinols, spirodienones, dibenzodioxocins, and $\alpha, \beta$-diaryl ethers, together with cinnamyl alcohol and cinnamaldehyde end-groups. 2D-NMR also indicated that the lignin of wheat straw is partially acylated ( $\sim 10 \%$ of all side chains), and exclusively at the $\gamma$-carbon of the side chain, with acetates and $p$-coumarates. DFRC analyses indicated that acetates preferentially acylate the $\gamma-\mathrm{OH}$ in guaiacyl $(12 \%)$ rather than in syringyl units $(1 \%)$, as has also been found to occur in other grasses and in contrast to what occurs in dicots. On the other hand, and despite $p$-coumarates' having been found acylating the $\gamma-\mathrm{OH}$, they were barely detectable as the monolignol conjugates after selectively cleaving $\beta$-ethers in lignin in the DFRC method, which seems to indicate that $p$ coumarates must be preferentially involved in structures other than $\beta$-ethers. Finally, we present the first evidence that the flavone tricin was found in wheat lignin, etherified by a G-type unit. If it is ultimately shown to have incorporated, in the cell wall, into the lignin by the radical coupling reactions that typify lignification (as it appears), the definition of lignin, and what constitutes a lignin monomer, will need further refinement.

\section{ASSOCIATED CONTENT}

\section{Supporting Information}

Section of the HMBC spectrum of wheat straw MWL showing the correlation of tricin $\mathrm{C}^{\prime}$ carbon and the proton at the $\beta$ position of a G-unit. This material is available free of charge via the Internet at http://pubs.acs.org.

\section{AUTHOR INFORMATION}

\section{Corresponding Author}

*Phone: +34-95-4624711. Fax: +34-95-4624002. E-mail: delrio@irnase.csic.es. 


\section{Funding}

This study has been funded by the Spanish project AGL201125379 , the CSIC project 201040E075, and the EU-project LIGNODECO (KBBE-244362). Dr. Jorge Rencoret thanks the CSIC for a JAE-DOC contract of the program "Junta para la Ampliación de Estudios" cofinanced by Fondo Social Europeo (FSE). P.P. thanks the Spanish Ministry of Science and Innovation for an FPI fellowship. J.R. was funded in part by the DOE Great Lakes Bioenergy Research Center (DOE Office of Science BER DE-FC02-807ER64494).

\section{Notes}

The authors declare no competing financial interest.

\section{ACKNOWLEDGMENTS}

We thank Manuel Angulo (CITIUS, University of Seville) for providing technical assistance in the NMR analyses and Dr. Yuki Tobimatsu (Univ. Wisconsin, Madison) for performing the GPC analyses.

\section{REFERENCES}

(1) Simmons, B. A.; Loque, D.; Ralph, J. Advances in modifying lignin for enhanced biofuels production. Curr. Opin. Plant Biol. 2010, 13, 313320.

(2) Ragauskas, A. J.; Williams, C. K.; Davison, B. H.; Britovsek, G.; Cairney, J.; Eckert, C. A.; Frederick, W. J.; Hallett, J. P.; Leak, D. J.; Liotta, C. L.; Mielenz, J. R.; Murphy, R.; Templer, R.; Tschaplinski., T. The path forward for biofuels and biomaterials. Science 2006, 311, 484489.

(3) Somerville, C.; Youngs, H.; Taylor, C.; Davis, S. C.; Long, S. P. Feedstocks for lignocellulosic biofuels. Science 2010, 329, 790-792.

(4) Sarkar, N.; Ghosh, S. K.; Bannerjee, S.; Aikat, K. Bioethanol production from agricultural wastes: An overview. Renewable Energy 2012, 37, 19-27.

(5) Kim, S.; Dale, B. E. Global potential bioethanol production from wasted crops and crop residues. Biomass Bioenergy 2004, 4, 361-375.

(6) Abramson, M.; Shoseyov, O.; Shani, Z. Plant cell wall reconstruction toward improved lignocellulosic production and processability. Plant Sci. 2010, 178, 61-72.

(7) Hendriks, A. T. W. M.; Zeeman, G. Pretreatments to enhance the digestibility of lignocellulosic biomass. Bioresour. Technol. 2009, 100, $10-18$.

(8) Agbor, V. B.; Cicek, N.; Sparling, R.; Berlin, A.; Levin, D. B. Biomass pretreatment: Fundamentals toward application. Biotechnol. Adv. 2011, 29, 675-685.

(9) Ralph, J.; Lundquist, K.; Brunow, G.; Lu, F.; Kim, H.; Schatz, P. F.; Marita, J. M.; Hatfield, R. D.; Ralph, S. A.; Christensen, J. H.; Boerjan, W. Lignins: Natural polymers from oxidative coupling of 4-hydroxyphenylpropanoids. Phytochem. Rev. 2004, 3, 29-60.

(10) Ralph, J. Hydroxycinnamates in lignification. Phytochem. Rev. 2010, 9, 65-83.

(11) Crestini, C.; Argyropoulos, D. S. Structural analysis of wheat straw lignin by quantitative ${ }^{31} \mathrm{P}$ and $2 \mathrm{D}$ NMR spectroscopy. The occurrence of ester bonds and $\alpha$-O-4 substructures. J. Agric. Food Chem. 1997, 45, $1212-1219$.

(12) Sun, R.; Lawther, J. M.; Banks, W. B. A tentative chemical structure of wheat straw lignin. Ind. Crops Prod. 1997, 6, 1-8.

(13) Sun, R. -C.; Sun, X. F.; Wang, S. Q.; Zhu, W.; Wang, X. Y. Ester and ether linkages between hydroxycinnamic acids and lignins from wheat, rice, rye, and barley straws, maize stems, and fast-growing poplar wood. Ind. Crops Prod. 2002, 15, 179-188.

(14) Sun, X.-F.; Sun, R. -C.; Fowler, P.; Baird, M. S. Extraction and characterization of original lignin and hemicelluloses from wheat straw. J. Agric. Food Chem. 2005, 53, 860-870.

(15) Banoub, J. H.; Benjelloun-Mlayah, B.; Ziarelli, F.; Joly, N.; Delmas, M. Elucidation of the complex molecular structure of wheat straw lignin polymer by atmospheric pressure photoionization quadru- pole time-of-flight tandem mass spectrometry. Rapid Commun. Mass Spectrom. 2007, 21, 2867-2888.

(16) Zhang, J.; Deng, H.; Lin, L.; Sun, Y.; Pan, C.; Liu, S. Isolation and characterization of wheat straw lignin from a formic acid process. Bioresour. Technol. 2010, 101, 2311-2316.

(17) Yang, Q.; Wu, S.; Lou, R.; Gaojin, L. V. Structural characterization of lignin from wheat straw. Wood Sci. Technol. 2011, 45, 419-431.

(18) Björkman, A. Studies on finely divided wood. Part I. Extraction of lignin with neutral solvents. Sven. Papperstidn. 1956, 59, 477-485.

(19) Tappi Test Methods 2004-2005; Tappi Press: Norcoss, GA 30092, USA, 2004.

(20) Browning, B. L. Methods of Wood Chemistry; Wiley-Interscience Publishers: New York, 1967; Vol. II.

(21) del Río, J. C.; Prinsen, P.; Rencoret, J.; Nieto, L.; Jiménez-Barbero, J.; Ralph, J.; Martínez, A. T.; Gutiérrez, A. Structural characterization of the lignin in the cortex and pith of elephant grass (Pennisetum purpureum) stems. J. Agric. Food Chem. 2012, 60, 3619-3634.

(22) Faix, O.; Meier, D.; Fortmann, I. Thermal degradation products of wood. A collection of electron-impact (EI) mass spectra of monomeric lignin derived products. Holz Roh-Werkstoff 1990, 48, 351-354.

(23) Ralph, J.; Hatfield, R. D. Pyrolysis-GC/MS characterization of forage materials. J. Agric. Food Chem. 1991, 39, 1426-1437.

(24) Kim, H.; Ralph, J.; Akiyama, T. Solution-state 2D NMR of ballmilled plant cell-wall gels in DMSO- $d_{6}$. Bioenergy Res. 2008, 1, 56-66.

(25) Rencoret, J.; Marques, G.; Gutiérrez, A.; Nieto, L.; Santos, J. I.; Jiménez-Barbero, J.; Martínez, A. T.; del Río, J. C. HSQC-NMR analysis of lignin in woody (Eucalyptus globulus and Picea abies) and non-woody (Agave sisalana) ball-milled plant materials at the gel state. Holzforschung 2009, 63, 691-698.

(26) Ralph, J.; Hatfield, R. D.; Quideau, S.; Helm, R. F.; Grabber, J. H.; Jung, H. -J. G. Pathway of $p$-coumaric acid incorporation into maize lignin as revealed by NMR. J. Am. Chem. Soc. 1994, 116, 9448-9456.

(27) Ralph, J.; Marita, J. M.; Ralph, S. A.; Hatfield, R. D.; Lu, F.; Ede, R. M.; Peng, J.; Quideau, S.; Helm, R. F.; Grabber, J. H.; Kim, H.; JimenezMonteon, G.; Zhang, Y.; Jung, H. -J. G.; Landucci, L. L.; MacKay, J. J.; Sederoff, R. R.; Chapple, C.; Boudet, A. M. Solution-state NMR of lignin. In Advances in lignocellulosics characterization; Argyropoulos, D. S., Ed.; Tappi Press: Atlanta, 1999; pp 55-108.

(28) Ralph, S. A.; Ralph, J.; Landucci, L. NMR database of lignin and cell wall model compounds; US Forest Prod. Lab.: One Gifford Pinchot Dr., Madison, WI 53705 (http://ars.usda.gov/Services/docs.htm?docid= 10491) (accessed: January 2009), 2004.

(29) Rencoret, J.; Marques, G.; Gutiérrez, A.; Ibarra, D.; Li, J.; Gellerstedt, G.; Santos, J. I.; Jiménez-Barbero, J.; Martínez, A. T.; del Río, J. C. Structural characterization of milled wood lignin from different eucalypt species. Holzforschung 2008, 62, 514-526.

(30) Rencoret, J.; Marques, G.; Gutiérrez, A.; Nieto, L.; JiménezBarbero, J.; Martínez, A. T.; del Río, J. C. Isolation and structural characterization of the milled wood lignin from Paulownia fortunei wood. Ind. Crops Prod. 2009, 30, 137-143.

(31) del Río, J. C.; Rencoret, J.; Marques, G.; Gutiérrez, A.; Ibarra, D.; Santos, J. I.; Jiménez-Barbero, J.; Zhang, L.; Martínez, A. T. Highly acylated (acetylated and/or $p$-coumaroylated) native lignins from diverse herbaceous plants. J. Agric. Food Chem. 2008, 56, 9525-9534.

(32) del Río, J. C.; Rencoret, J.; Gutiérrez, A.; Nieto, L.; JiménezBarbero, J.; Martínez, A. T. Structural characterization of guaiacyl-rich lignins in flax (Linum usitatissimum) fibers and shives. J. Agric. Food Chem. 2011, 59, 11088-11099.

(33) Martínez, A. T.; Rencoret, J.; Marques, G.; Gutiérrez, A.; Ibarra, D.; Jiménez-Barbero, J.; del Río, J. C. Monolignol acylation and lignin structure in some nonwoody plants: A 2D-NMR study. Phytochemistry 2008, 69, 2831-2843.

(34) Ralph, J.; Landucci, L. L. NMR of Lignins. In Lignin and Lignans; Advances in Chemistry; Heitner, C., Dimmel, D. R., Schmidt, J. A., Eds.; CRC Press (Taylor \& Francis Group): Boca Raton, FL, 2010; pp 137234.

(35) Kim, H.; Ralph, J. Solution-state 2D NMR of ball-milled plant cell wall gels in DMSO- $d_{6} /$ pyridine- $d_{5}$. Org. Biomol. Chem. 2010, $8,576-$ 591. 
(36) Lu, F.; Ralph, J. Derivatization followed by reductive cleavage (DFRC method), a new method for lignin analysis: protocol for analysis of DFRC monomers. J. Agric. Food Chem. 1997, 45, 2590-2592.

(37) Lu, F.; Ralph, J. The DFRC method for lignin analysis. Part 1. A new method for $\beta$-aryl ether cleavage: lignin model studies. J. Agric. Food Chem. 1997, 45, 4655-4660.

(38) Lu, F.; Ralph, J. The DFRC method for lignin analysis. 2. Monomers from isolated lignin. J. Agric. Food Chem. 1998, 46, 547-552.

(39) Ralph, J.; Lu, F. The DFRC method for lignin analysis. 6. A simple modification for identifying natural acetates in lignin. J. Agric. Food Chem. 1998, 46, 4616-4619.

(40) del Río, J. C.; Marques, G.; Rencoret, J.; Martínez, A. T.; Gutiérrez, A. Occurrence of naturally acetylated lignin units. J. Agric. Food Chem. 2007, 55, 5461-5468.

(41) Valmaseda, V.; Martínez, M. J.; Martínez, A. T. Kinetics of wheat straw solid-state fermentation with Trametes versicolor and Pleurotus ostreatus - Lignin and polysaccharide alteration and production of related enzymatic activities. Appl. Microbiol. Biotechnol. 1991, 35, 817-823.

(42) Kondo, T.; Ohshita, T.; Kyuma, T. Comparison of characteristics of soluble lignins from untreated and ammonia-treated wheat straw. Anim. Feed Sci. Technol. 1992, 39, 253-263.

(43) Scalbert, A.; Monties, B.; Lallemand, J.-Y.; Guittet, E.; Rolando, C. Ether linkage between phenolic acids and lignin fractions from wheat straw. Phytochemistry 1985, 24, 1359-1362.

(44) Lam, T. B. T.; Iiyama, K.; Stone, B. A. Cinnamic acid bridges between cell wall polymers in wheat and phalaris intemodes. Phytochemistry 1992, 31, 1179-1183.

(45) Grabber, J. H.; Ralph, J.; Hatfield, R. D. Cross-linking of maize walls by ferulate dimerization and incorporation into lignin. J. Agric. Food Chem. 2000, 48, 6106-6113.

(46) del Río, J. C.; Gutiérrez, A.; Rodríguez, I. M.; Ibarra, D.; Martínez, A. T. Composition of non-woody plant lignins and cinnamic acids by PyGC/MS, Py/TMAH and FT-IR. J. Anal. Appl. Pyrol. 2007, 79, 39-46.

(47) del Río, J. C.; Martín, F.; González-Vila, F. J. Thermally assisted hydrolysis and alkylation as a novel pyrolytic approach for the structural characterization of natural biopolymers and geomacromolecules. Trends Anal. Chem. 1996, 15, 70-79.

(48) Ralph, J.; Bunzel, M.; Marita, J. M.; Hatfield, R. D.; Lu, F.; Kim, H.; Schatz, P. F.; Grabber, J. H.; Steinhart, H. Peroxidase-dependent cross-linking reactions of $p$-hydroxycinnamates in plant cell walls. Phytochem. Rev. 2004, 3, 79-96.

(49) Ralph, J.; Hatfield, R. D.; Piquemal, J.; Yahiaoui, N.; Pean, M.; Lapierre, C.; Boudet, A. M. NMR characterization of altered lignins extracted from tobacco plants down-regulated for lignification enzymes cinnamyl-alcohol dehydrogenase and cinnamyl-CoA reductase. Proc. Natl. Acad. Sci. U.S.A. 1998, 95, 12803-12808.

(50) Wenzig, E.; Kunert, O.; Ferreira, D.; Schmid, M.; Schühly, W.; Bauer, R.; Hiermann, A. Flavonolignans from Avena sativa. J. Nat. Prod. 2005, 68, 289-292.

(51) Chang, C. L.; Wang, G. J.; Zhang, L. J.; Tsai, W. J.; Chen, R. Y.; $\mathrm{Wu}$, Y. C.; Kuo, Y. H. Cardiovascular protective flavolignans and flavonoids from Calamus quiquesetinervius. Phytochemistry 2010, 71, 271-279.

(52) Zhou, J. M.; Ibrahim, R. K. Tricin - a potential multifunctional nutraceutical. Phytochem. Rev. 2010, 9, 413-424.

(53) Grabber, J. H.; Schatz, P. F.; Kim, H.; Lu, F.; Ralph, J. Identifying new lignin bioengineering targerts: 1 . Monolignol-substitute impacts on lignin formation and cell wall fermentability. BMC Plant Biol. 2010, 10, 114.

(54) Sederoff, R. R.; MacKay, J. J.; Ralph, J.; Hatfield, R. D. Unexpected variation in lignin. Curr. Opin. Plant Biol. 1999, 2, 145-152.

(55) Ralph, J.; Peng, J.; Lu, F.; Hatfield, R. D. Are lignins optically active? J. Agric. Food Chem. 1999, 47, 2991-2996.

(56) Ralph, J.; Brunow, G.; Harris, P. J.; Dixon, R. A.; Schatz, P. F.; Boerjan, W. Lignification: Are lignins biosynthesized via simple combinatorial chemistry or via proteinaceous control and template replication? In Recent Advances in Polyphenol Research; Daayf, F., El Hadrami, A., Adam, L., Ballance, G. M., Eds.; Wiley-Blackwell Publishing: Oxford, U.K., 2008; Vol. 1, pp 36-66.
(57) Umezawa, T. Diversity in lignan biosynthesis. Phytochem. Rev. 2004, 2, 371-390.

(58) Boerjan, W.; Ralph, J.; Baucher, M. Lignin biosynthesis. Annu. Rev. Plant Biol. 2003, 54, 519-549.

(59) Lu, F.; Ralph, J. Detection and determination of $p$-coumaroylated units in lignins. J. Agric. Food Chem. 1999, 47, 1988-1992.

(60) Ralph, J. An unusual lignin from kenaf. J. Nat. Prod. 1996, 59, $341-342$.

(61) Lu, F.; Ralph, J. Novel tetrahydrofuran structures derived from $\beta-\beta$-coupling reactions involving sinapyl acetate in Kenaf lignins. Org. Biomol. Chem. 2008, 6, 3681-3694.

(62) Terashima, N.; Fukushima, K.; He, L.-F.; Takabe, K. Comprehensive model of the lignified plant cell wall. In Forage Cell Wall Structure and Digestibility; Jung, H. G., Buxton, D. R., Hatfield, R. D., Ralph, J., Eds.; American Society of Agronomy, Crop Science Society of America, Soil Science Society of America: Madison, 1993; pp 247270. 


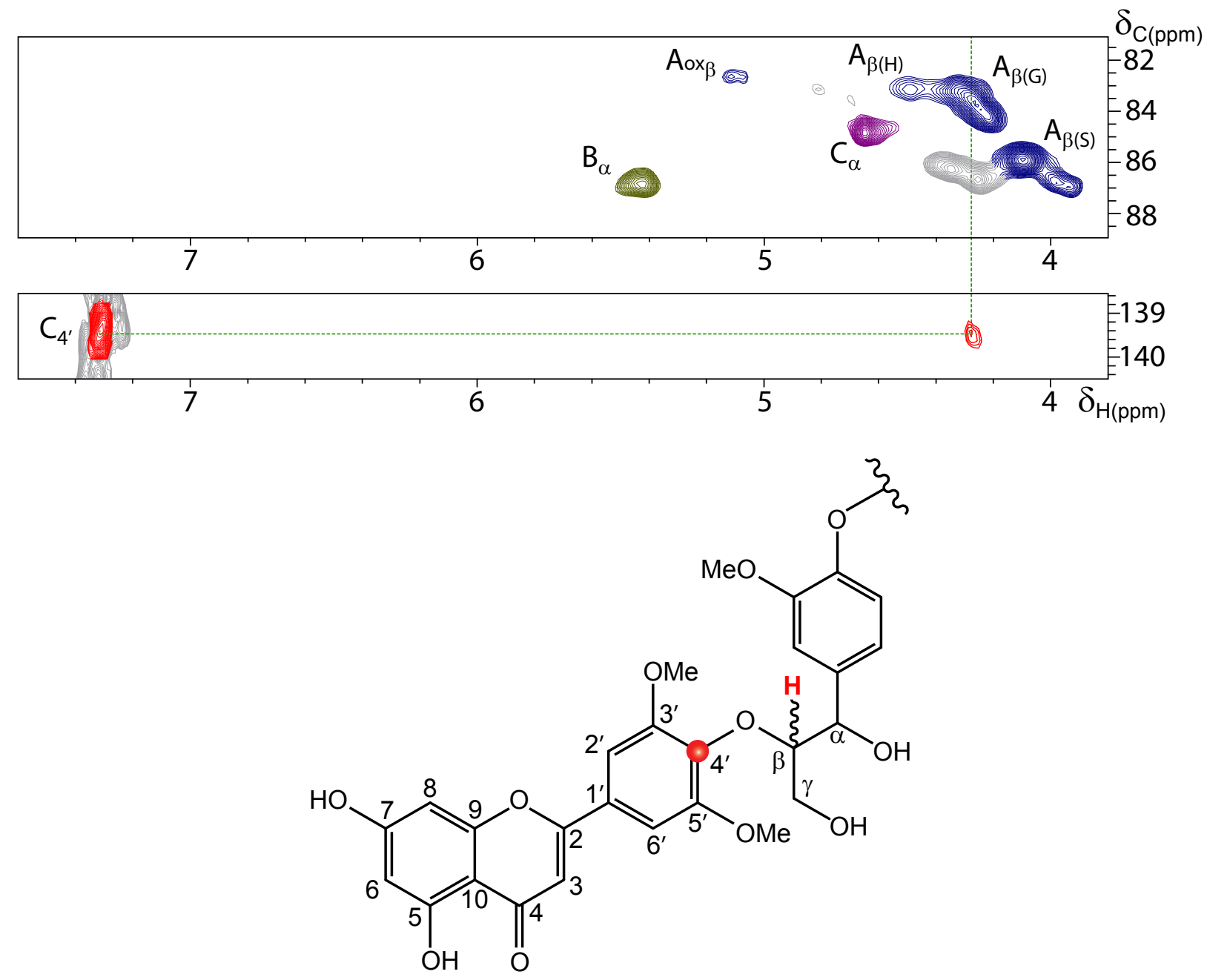

Supplementary Figure 1. Section of the HMBC spectrum of wheat straw MWL showing the correlation for the tricin $\mathrm{C}^{\prime}$ carbon (at $139.5 \mathrm{ppm}$ ) and the proton at the $\beta$-position of a G-unit at $4.28 \mathrm{ppm}$ (bottom). The section of the HSQC spectrum for the $\mathrm{C} \beta-\mathrm{H} \beta$ correlations of the $\beta-\mathrm{O}-4^{\prime}$ alkyl-aryl ethers is also shown (top). The structure illustrates the likely incorporation of tricin into the lignin polymer through a $4^{\prime}-\mathrm{O}-\beta$ ether linkage with a guaiacyl unit. 